\title{
Sudden changes in fluvial style across the Permian-Triassic boundary in the eastern Iberian Ranges, Spain: Analysis of possible causes
}

\author{
Alfredo Arche* , José López-Gómez \\ Instituto de Geología Económica, CSIC-UCM, Facultad de Geología, Universidad Complutense, \\ Antonio Novais 2, 28040 Madrid, Spain
}

\begin{abstract}
The sedimentary record of the Late Permian and Early Triassic of the eastern Iberian Ranges shows four major, sudden, or very rapid, vertical changes in fluvial style. The Late Permian sedimentary cycle starts with the Boniches Formation, of alluvial fan-braided fluvial origin, which grades vertically over within a few metres into the Alcotas Formation, deposited by low to high sinuosity, avulsion-prone rivers with extensive floodplains. The Alcotas Formation contains calcimorphic soils, plant remains and pollen and spore assemblages. However, the upper third of the unit is devoid of all organic remains and soils and is characterized by a dominant red colour, the sandstone levels were deposited by high-sinuosity, meandering rivers. This major change took place during the Late Permian and is probably coeval with the emplacement of the Emeishan basaltic Large Igneous Province (LIP) in SE China. Rocks of the Boniches and Alcotas Formations are separated by an angular unconformity from the overlying strata, which consist of the Late Permian conglomeratic Hoz del Gallo Formation, of alluvial fan-gravel braided fluvial origin and the sandy Cañizar Formation, of low-sinuosity sandy river origin. The PermianTriassic boundary lies, probably between the upper part of the Hoz del Gallo Formation and the first metres of the Cañizar Formation. Late Permian pollen and spore assemblages have been found in the Hoz del Gallo Formation but the Cañizar Formation is barren, with the exception of an Anisian (Middle Triassic) assemblage at the top. Tectonic extensional pulses in the Iberian Basin caused the changes observed between the lower and upper parts of the Boniches Formation, at the base of the Hoz del Gallo Formation and between the lower and upper part of this Formation. The changes observed in the uppermost part of the Alcotas Formation are not easily explained by tectonic causes, nor those in the passage from the Hoz del Gallo Formation to the Cañizar Formation. Similar sedimentary characteristics of the sandy Cañizar Formation such as amalgamated sandstone bodies, erosion and reactivation surfaces, dominant trough cross-stratification, tabular geometry, absence of plant remains and pollen and spores, and absence of silts and clays to those of coeval formations in places as far away as Australia, South Africa and Brazil suggest a global rather than local cause for these abrupt changes in fluvial style. This global cause was probably die-off of plant cover over extensive areas of the catchment, related to the end of the
\end{abstract}

\footnotetext{
* Corresponding author. Tel.: +34 91 3974818; fax: +34 913944808.

E-mail address: aarche@geo.ucm.es (A. Arche).
} 
Permian mass extinction and possibly related to the emplacement of the West Siberian basaltic Large I Province (LP), responsible for drastic amospheric and marine changes.

Keywerds: Permian; Triassic; Iberian Ranges; Spain; Fluvial sedimentology; Climatic changes

\section{Introduction}

The Iberian Ranges, a linear alpine compressive structure in central and eastern Spain (Figs. 1A and 2), was formed during Late Cenøzic times along the northeastern edge of the Iberian microplate (Virgili et al., 1983; Sopeña et al., 1988; López-Gómez and Arche, 1993; Arche and López-Gómez, 1996). Its Permian and Triassic sediments were deposited in a rift basin, the Iberian Basin, which breadly occupied the same geographical location and was related to other contemporaneous basins such as the Ebro, Pyrenean, Catalan and Cuenca-Valencia Basins (Fig. 1B). In the Iberian Ranges, the Permian-Triassic transition occurs in non-marine strata of alluvial origin.

On a gløbal scale, a mass extinction at the end of Permian is considere as the most consequential of the five major Phanaerøzic mass extinctions (Erwin, 1994). Detailed palaentølogical studies on marine sediments point to a sudden rather than protracted event (Jin et al., 2000). However, far less information has been $\bullet$ btained from continental sediments, in which the Permian-Triassic boundary is still difficult to pinpøint precisely, mainly because of incomplete $\bullet$ r absent chronostratigraphical data. Abrupt changes have, nevertheless, been $\bullet$ bserved in the characteristics of continental sediments across the end of the Permian related to the Permian-Triassic boundary, such as those indicated by facies and stratigraphic markers (Ward et al., 2000), chemostratigraphic markers (Morante, 1996; Krull and Retallack, 2000) or non-marine vertebrate faunas (Smith and Ward, 2001). Well-described examples of changes in sediment characteristics for this particular period of time have been attributed to changes in fluvial style (Smith, 1995; Fielding and Alexander, 2001; Retallack et al., 2003; Miall and Jones, 2003). Ward et al. (2000) relate rapid and extensive majør die-off of røoted plant life t॰ altered river morphølogy across the Permian-Triassic boundary in the Karøo Basin, Søuth Africa. Another, less knøwn mass extinction tøok place at the end of the Middle
Permian (Guadalupian) (Wignall, 2001; Zhøu et al., 2002; Courtillot and Renne, 2003) related the emplacement of the Emeishan basaltic Large Igneøus Prøvince (LP) in SE China; this event could be the main cause of sudden fluvial changes in the Upper Permian sedimentary record of the Iberian Ranges. The aim of the present study is to contribute to the analysis of possible causes explaining sudden fluvial style changes across the end-Permian and Permian-Triassic boundary through the detailed study of the well-developed continental sections of eastern Iberian Ranges.

\section{Geological setting}

The Permian-Triassic sedimentary basins were formed under an extensional tectonic regime with several synrift-pestrift phases occurring from the Early Permian (Autunian, approx. $290 \mathrm{Ma}$.) to the Late Triassic-Early Jurassic (abøut 205 Ma.) and beyond (Arche and López-Gómez, 1996).

The Iberian Basin developed on a hercynian basement of Ordovician-Silurian slates and quartzites deformed in kilometre-size structures trending NW$\mathrm{SE}$, with a general eastwards vergence (Capote and

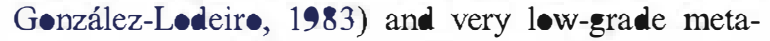
morphism (chlorite-pyrophyllite zone) along the suture line of the Iberian and Ebrø microplates.

The extensional basin boundary faults were, in part, reactivated hercynian or older alignments trending NW-SE and N-S. The long and complex evelution -f this basin has been investigated by Salas and Casas (1993), Døblas et al. (1993), Arche and López-Gómez (1996) and Van Wees et al. (1998), among others.

The rock record for the Permian-Triassic time interval in the Iberian Basin includes velcanic and sedimentary rocks; its division int formations being well established, as is the presence of three regional angular unconformities and/or hiatuses in the record. Continental deposits are found from the Early Permian to the Middle Triassic (Anisian) and several 


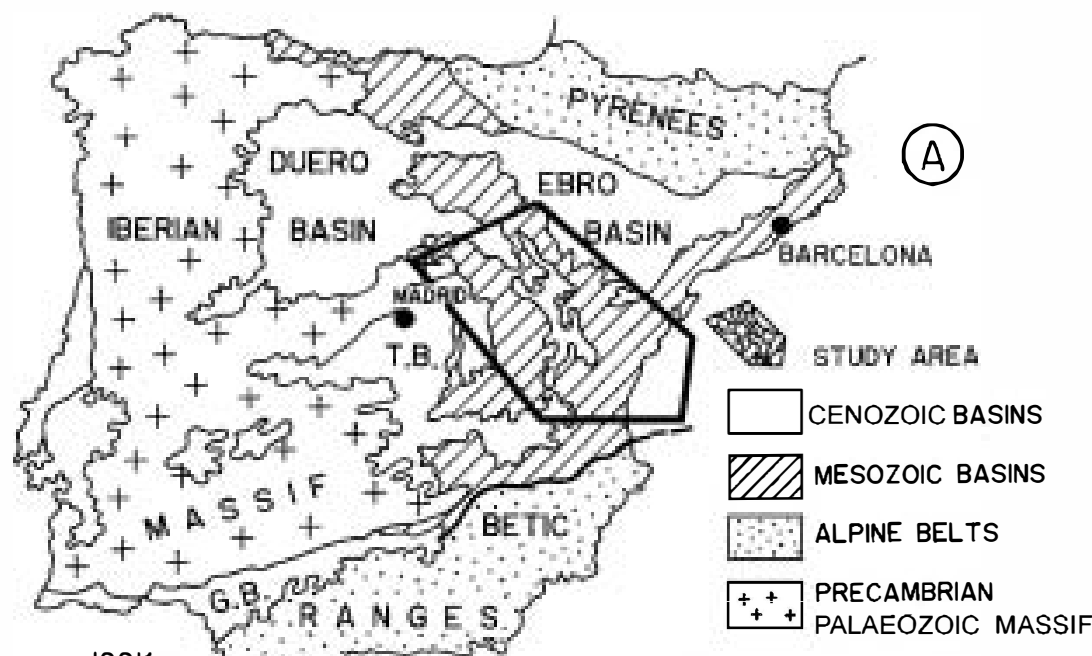

$100 \mathrm{Km}$

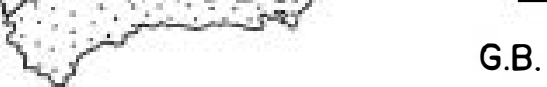

G.B. GUADALQUIVIR BASIN

T.B. TAJO BASIN

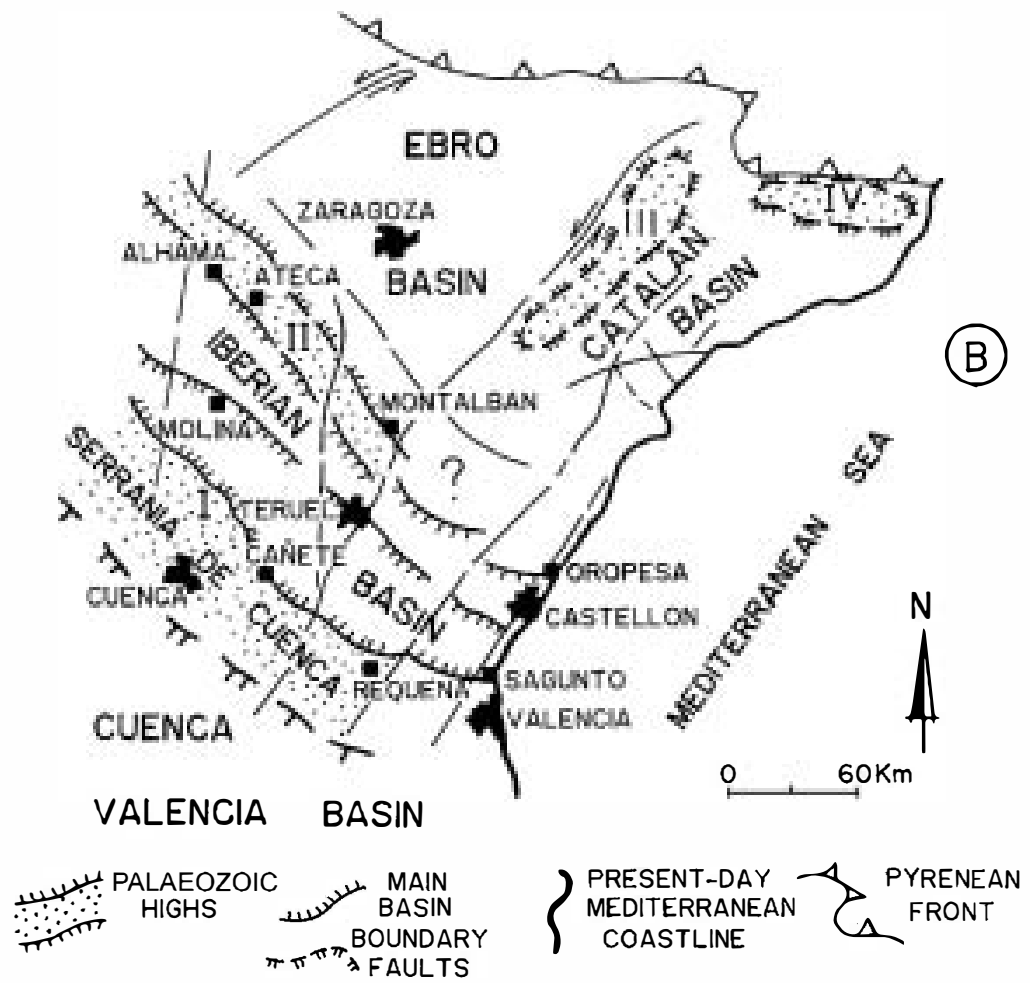

Fig. 1. (A) Main geologic units of the Iberian Peninsula and study area. (B) Tentative reconstruction of the sedimentary basins at the base of the Triassic, main Paleozoic highs and basin boundary fault systems and related accommodation faults. I—Serranía de Cuenca High, II—AtecaMontalban High, III—Lérida High, IV—Gerona High. 


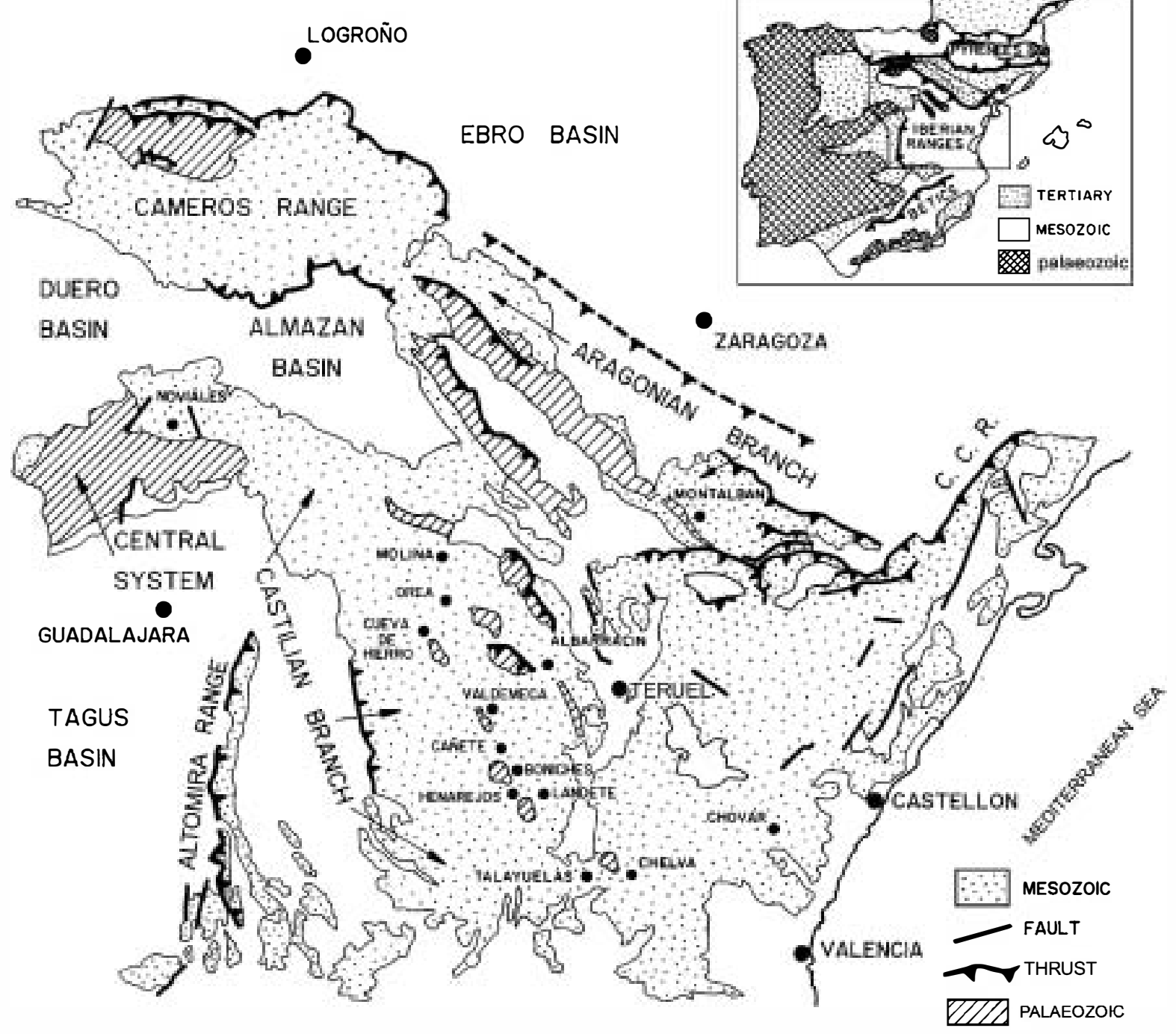

Fig. 2. Present-day configuration of the Iberian Ranges and associated basins with localities cited in the text (López-Gómez et al., 2002, modified).

transgressive pulses deposited shallow marine carbonates and evaporites in the eastern part of the basin, usually passing laterally into coastal and continental siliciclastics along the axis of the basin. These deposits have been extensively described in the literature and are reviewed in Sopeña et al. $(1983,1988)$ and López-Gómez et al. (1998, 2002).

During the Permian and Early Triassic, a narrow longitudinal Palaeozoic high, the Ateca-Montalban High (Fig. 1B), separated the Iberian from the Ebro Basin. To the SW, another ill-defined palaeozoic high, the Serranía de Cuenca High, separated the Iberian Basin from the Cuenca-Valencia Basin (Fig. 1B). The structural framework of the Iberian Basin also included a transverse palaeozoic high, the OreaCueva de Hierro High, trending NE-SW. The present-day configuration of the Iberian Ranges can be described as two Palaeozoic-Mesozoic chains separated by a Cenozoic basin, the Aragonese and Castilian Branches that roughly mimic the PermianTriassic Basin and its bounding palaeozoic highs (Fig. 2). 
The structural origins and evolution of the Iberian Basin along with subsidence changes and its quantitative study during the Permian-Triassic synrift-postrift stages have been reviewed by Alvaro (1987), Sánchez-Moya et al. (1992), Salas and Casas (1993), Roca et al. (1994), Arche and López-Gómez (1996) and Van Wees et al. (1998).

\section{The Permian and Triassic sedimentary record}

The Permian-Triassic rock record of the Iberian Basin has been divided into seven major sedimentary successions, including one or more formations, each bounded by unconformities and/or hiatuses (Pérez-Arlucea and Sopeña, 1985; López-Gómez and Arche, 1992; Arche et al., 2004). Of these successions, only the three lowermost (Fig. 3 and Plate I) are relevant to the questions addressed in this paper.

\subsection{First sedimentary succession}

The oldest sediments and associated volcanic rocks of Early Permian (Autunian) age were deposited in a series of isolated half-graben basins of kilometric size, from Noviales in the NW to Chóvar in the SE (Fig. 2) (Hernando, 1977; Sopeña, 1979; Ramos, 1979; Pérez-Arlucea and Sopeña, 1985; López-Gómez and Arche, 1994). These sediments are represented by the Ermita and Tabarreña Formations (Fig. 3).

The lower part of the succession contains lava flows and pyroclastics of andesitic to basaltic composition, dated as $282 \pm 1.2 \mathrm{Ma}$. (Hernando, 1977) or $283 \pm 2.5 \mathrm{Ma}$. (Lago et al., 2002), which are overlain by variegated siltstones, dolomites and red breccias. Coal measures are found in the Henarejos outcrop (Fig. 2)

\subsection{Second sedimentary succession}

Bounded by two angular unconformities, this succession was deposited in a single, symmetric graben basin of complex geometry (Arche and LópezGómez, 1996). It consists of quartzite conglomerates (Boniches Formation) of limited lateral extension and red siltstones, sandstones and conglomerates (Alcotas

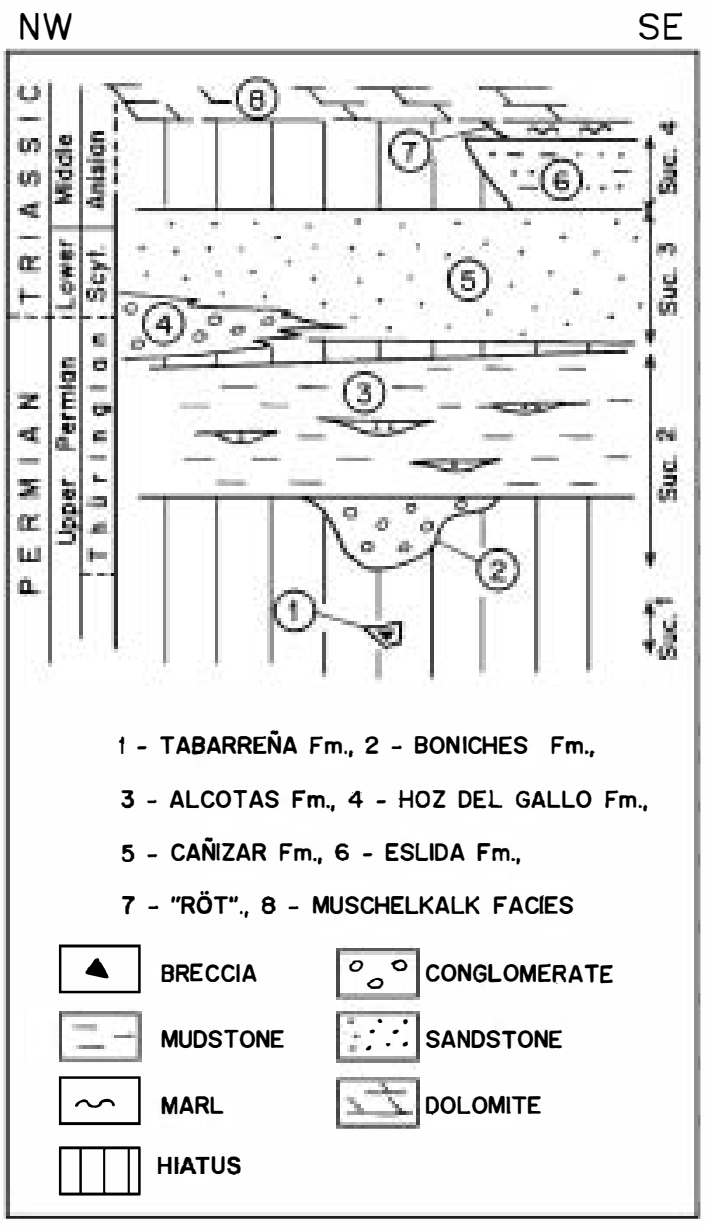

Fig. 3. Scheme of the Permian and Triassic sedimentary successions in the Iberian Ranges and associated unconformities and hiatuses.

Formation and its time-equivalent Montesoro and Tormón Formations).

According to pollen and spore assemblages found in many areas across the basin (Doubinger et al., 1990; Sopeña et al., 1995), succession two is Upper Permian (Thuringian, sensu Visscher, 1971). The biostratigraphic data that justify the attribution of ages to the four formations considered in this paper will be discussed in Section 4.

\subsection{Third sedimentary succession}

Found all along the basin and also deposited as a single, symmetric complex graben, this cycle consists of quartzite conglomerates (Hoz del Gallo Formation) 

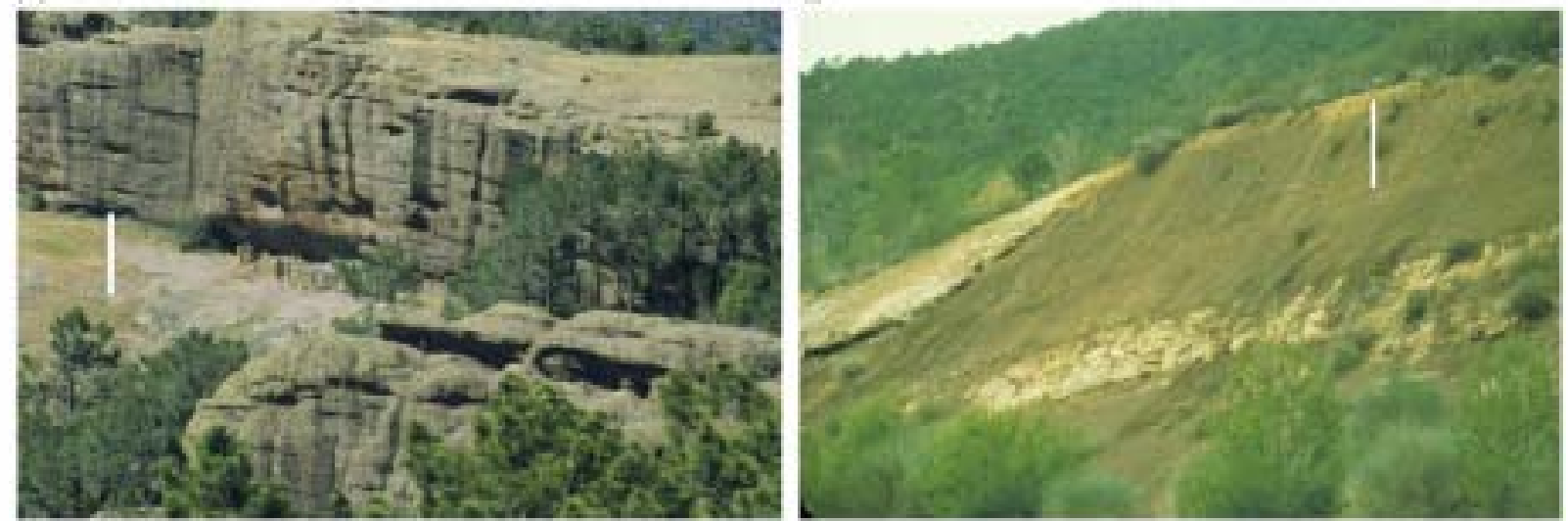

C

D
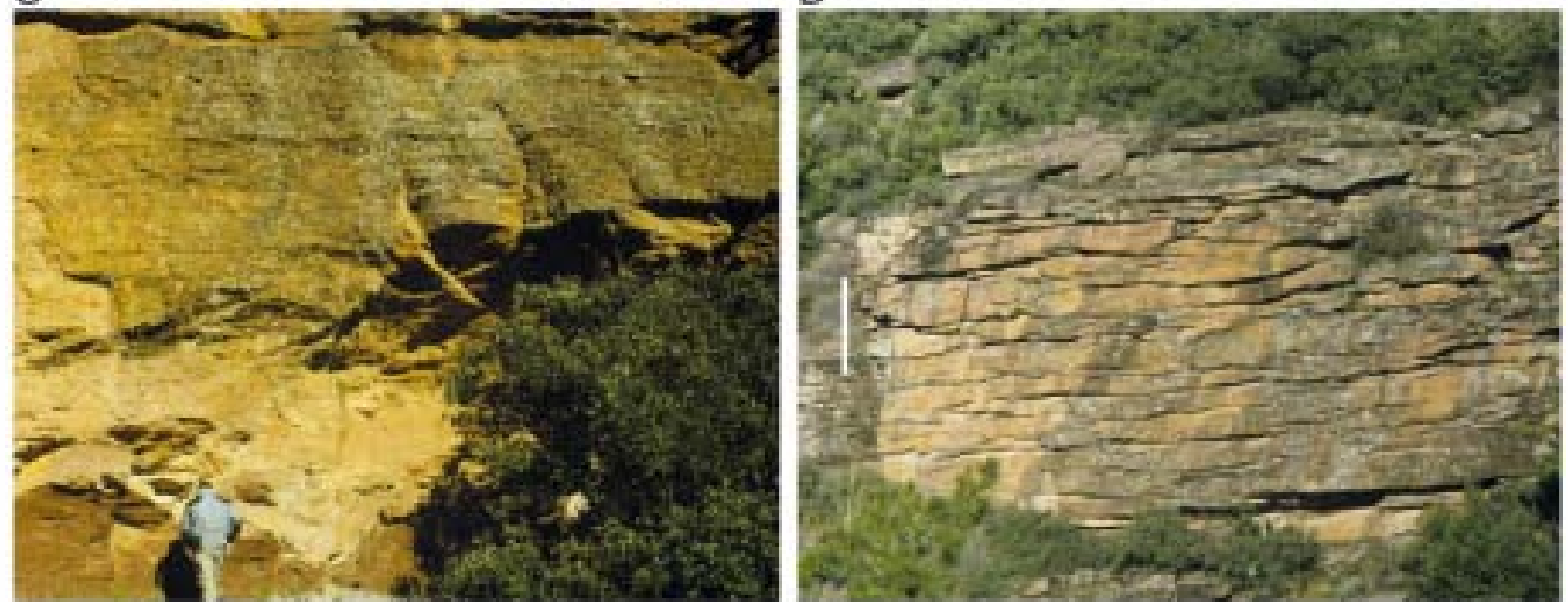

Plate I. Field aspect of the Sedimentary Formations studied in this paper

(A) Lower and middle part of the Boniches Formation in Boniches area.

(B) Lower part of the Alcotas Formation in Cañete area showing intercalated conglomeratic channel bodies and flood-plain red mudstones.

(C) Upper member of the Hoz del Gallo Formation in Cañete area lying unconformably on the Alcotas Formation.

(D) Lower part of the Cañizar Formation in the Cañete area with complex multilateral multi-storey units.

The bar scale in photographs: $A$ and $\mathbf{B}=5 \mathrm{~m} ; \mathbf{D}=3 \mathrm{~m}$. Panel C: man standing at the base of the outcrop is $1.70 \mathrm{~m}$ high. (For interpretation of the references to colour in this figure legend, the reader is referred to the web version of this article.)

of limited lateral extension overlain by pink to red sandstones (Cañizar Formation and its time-equivalent Rill• de Gall• Førmation) (Fig. 3).

The succession age ranges from Late Permian (Thuringian) at the base (Ramos, 1979; Ramos and Doubinger, 1979) to Middle Triassic (Anisian) at the top (Doubinger et al., 1990), according to palynomorph floras in both formations. The PermianTriassic boundary lies within this succession.
The conglømerate units of the upper cycle are of limited lateral extension, but the others (Alcotas and Cañizar Formations) appear all along the Iberian Basin. For a recent analysis of possible lateral correlations between these and other formations and unconformities and hiatuses along the Iberian Basin and the conterminous Ebr and Catalan Basins, as well as a revision of the stratigraphic nømenclature of the depøsits of the Permian-Triassic 


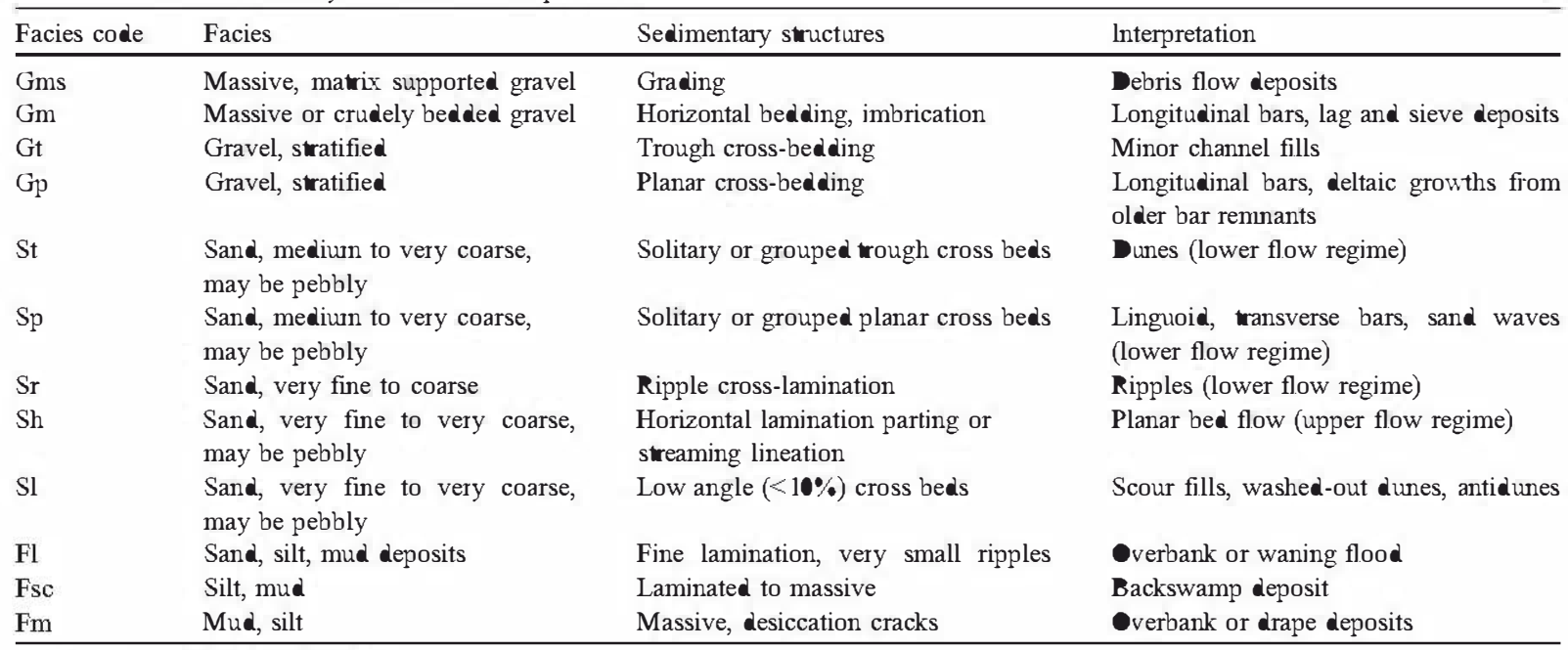

Modified after Miall (1978, 1992).

interval, see López-Gómez et al. (2002) and Arche et al. (2004).

The Cañizar Formation is conformably •verlain by the fourth succession, the continental Eslida Formation to the SE of the Iberian Basin or by the fifth succession via a hiatus. It consists of the lower Muschelkalk facies of late Anisian age (LópezGómez et al., 1998).

In this paper, we use the nomenclature of Miall $(1978,1992)$ to describe the sedimentary facies (Table 1).

\section{Sedimentary evolution of the alluvial deposits}

\subsection{Late Permian succession}

\subsubsection{Boniches Conglomerate Formation}

This unit (Fig. 4 and Plate IA) lies on an angular unconformity $\bullet$ the lower Palae zøic basement or, locally, on the Early Permian Tabarreña Breccia Førmation or on the uppermost Carboniferous (Stephanian C)-Lower Permian (Autunian) (?) Minas de Henarejos coal measures, and represents the sediments of the second major sedimentary succession in the eastern Iberian Ranges. According to pollen and spores assemblages found near the top of the unit in Talayuelas (Fig. 2), its age is Late Permian (early Thuringian, possibly zøne 30 of Gorsky et al., 2003).

Sedimentation of the Boniches Formation was controlled by the activity of the basin boundary fault system to the SW, the Serranía de Cuenca Fault (López-Gómez and Arche, 1997) (Fig. 1B), which created steep relief in the footwall block and short, steep transverse drainage networks. Lateral thickness markedly changes from $130 \mathrm{~m}$ in the central part of the basin (Henarejes) to less than $30 \mathrm{~m}$ in the NW and SE (Valdemeca and Chelva).

The lowermost member (Løwer Conglømerates) evolves vertically from massive deposits int finingupwards sequences of the Gms-Gm-Sh type to fining- or coarsening-fining upwards Gp-Gt-St-Sh type sequences. These are interpreted as proximal alluvial fan facies with palaecurrents transverse to the basin axis (Fig. 4). They evolved from longitudinal bars formed by diffuse gravel sheets migrating over the bar core to bar-and-channel complexes with superimposed bigh- and low-stage deposits (Ashmore, 1991; Crowley, 1983; Miall, 1981; López-Gómez and Arche, 1997).

The tw $\bullet$ intermediate members (Upper Conglømerates 1 and 2, UC-1 and UC-2, respectively, in Fig. 4) are similar to the upper part of the Lower Conglomerates (L.C.), dominated by fining-upwards sequences of type Gp-Gt-St-Sp-Sh, sømetimes trun- 


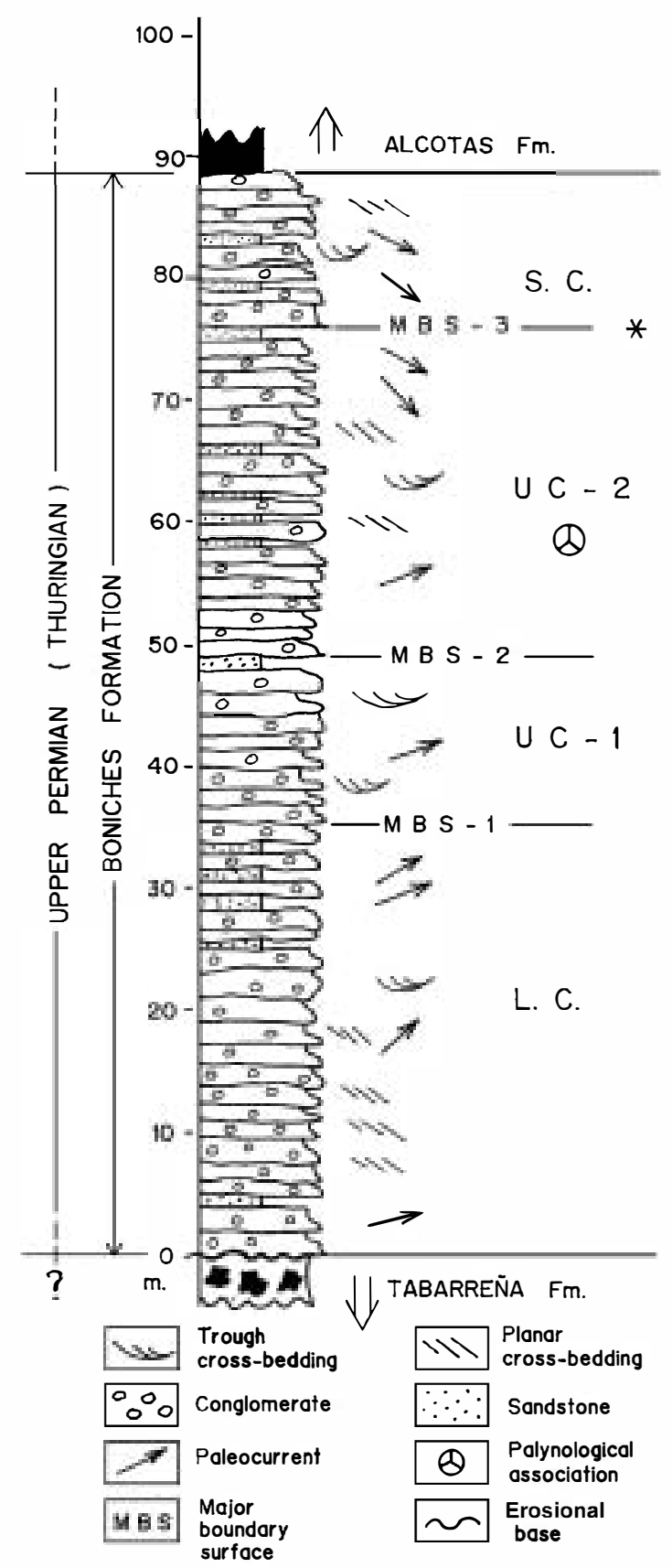

Fig. 4. Type section of the Boniches Conglomerate Formation near Cañete. The star marks the position of the first sudden change in fluvial style. L.C.: Lower Conglomerates; UC-1: Upper Conglomerates 1; UC-2: Upper Conglomerates 2; S.C.: Sandy Conglomerates; MBS: Main Boundary Surface. cated and vertically repeated. They are interpreted as transverse and composite mid-channel bars and associated low-stage sand bars in medial and distal alluvial fan environments related to braided fluvial systems.

The uppermost member (Sandy Conglomerates, S.C., in Fig. 4) consists of thin, fining-upwards sequences of the type $\mathrm{Gp}-\mathrm{St}-\mathrm{Sp}$, and show a sudden increase in sand content (up to $50 \%$ ). It is interpreted as deposits in medium to distal reaches of braided, bed load river systems (López-Gómez and Arche, 1997). It represents a sudden change in fluvial style marked by petrographic and internal structures variation (Fig. 4).

Palaeocurrents point NE in the lower two members and most of the third one with a mean dispersal of approximately $40^{\circ}-50^{\circ}$, drawing a transverse drainage pattern. At the top of the Upper Conglomerates 2, they switch to the SE all along the basin, passing into an axial drainage system. The change is sudden, indicating considerable palaeogeographical change.

\subsubsection{Alcotas Siltstone and Sandstone Formation}

The Alcotas Formation, lying conformably on the Boniches Formation or unconformably on the hercynian basement, is unconformably overlain by the $\mathrm{Hoz}$ del Gallo or Cañizar Formations (López-Gómez, 1985; López-Gómez and Arche, 1992). It consists of red siltstones and sandstones with minor presence of conglomerate lenses (Fig. 5 and Plate IB).

Thicknesses vary from $82 \mathrm{~m}$ in Valdemeca to 168 $\mathrm{m}$ in Chelva. The formation crops out along the entire Iberian Ranges except for the Cueva de Hierro-Orea Palaeozoic high.

Red siltstones are the dominant lithology (about $70 \%$, comprised of quartz, illite and kaolinite (Alonso-Azcárate et al., 1997) and minor amounts of feldspars and hematite. The illite/kaolinite ratio increases in the SE. Red to pink sandstones (about $27 \%$ ) consist of subrounded quartz and feldspar grains and mica flakes with clay matrix and quartz cements. Bulk lithology changes from dominant protoquartzites-greywackes in the Boniches area to arkoses in Landete, and again to protoquartzites in Chelva (López-Gómez, 1985).

The age of the Alcotas Formation is well constrained through several upper Permian (Thuringian) pollen and spore assemblages found in the Central and 


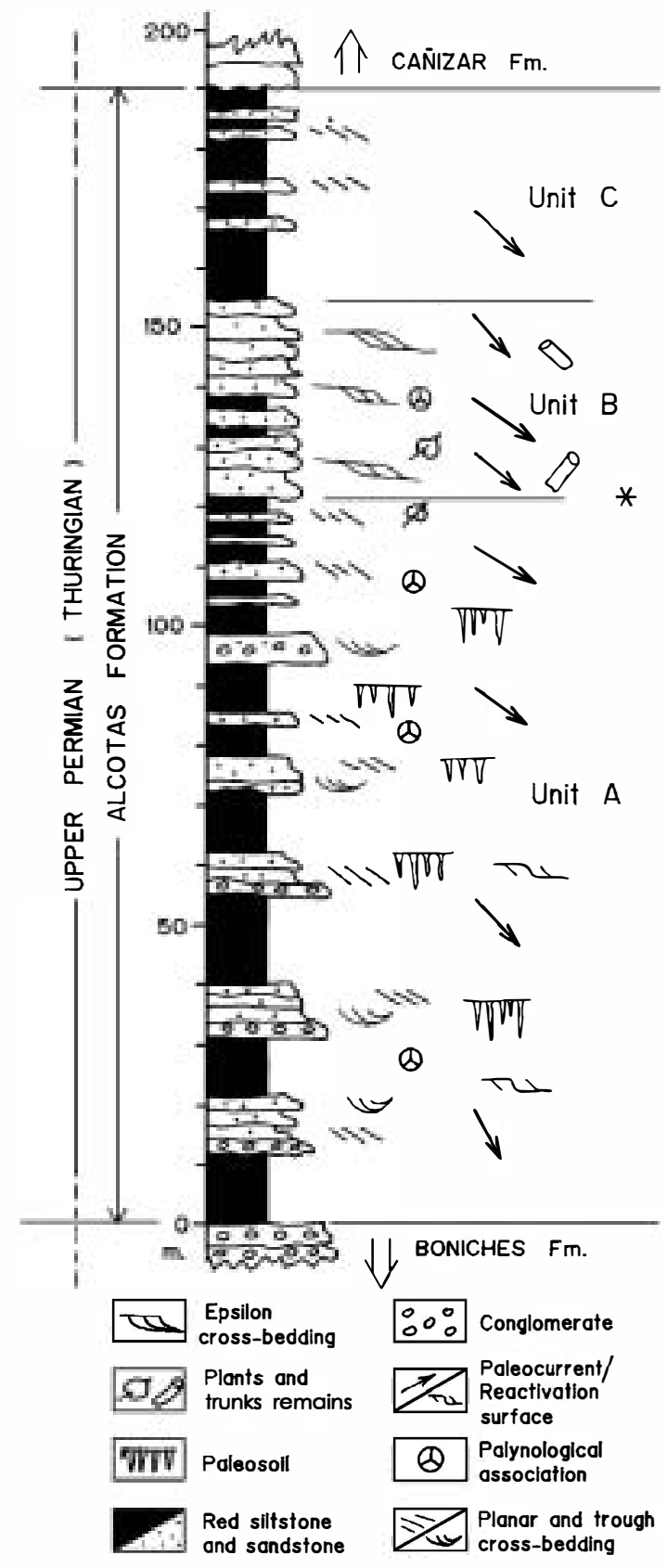

Fig. 5. Type section of the Alcotas Siltstone and Sandstone Formation near Boniches village. $\left({ }^{*}\right)$ Position of the second sudden change in fluvial style.

SE Iberian Ranges (Ramos and Doubinger, 1979; Doubinger et al., 1990; Boulouard and Viallard, 1971; Sopeña et al., 1995).
The formation can be divided into three finingupwards units (Fig. 5, Units A, B and C) using sharp surfaces that can be traced over most of the Iberian Ranges. The lower unit (Fig. 5, Unit A) is 20-40 $\mathrm{m}$ thick and consists of lensoidal conglomerate bodies, usually isolated, 95-120 m wide and 4-6 m thick with an erosional base and flat top embedded in red siltstones. The dominant vertical sequence is of the Gt-Gp-Sh-Sr type, and has lateral accretion and reactivation surfaces that do not always reach the base of the body. Amalgamated bodies with Sp-Sh and GtSp-St elementary sequences also appear.

Siltstone facies are usually massive (Fm facies) or laminated with rippled intervals (Fl and Fsc facies). They represent about $70 \%$ of the interval. The unit has calcic palaeosols containing nodular and laminar structures up to $20 \mathrm{~cm}$ thick. Most of the pollen and spores assemblages of Thuringian age found in the Iberian Ranges occur in this interval (Doubinger et al., 1990).

Unit A is interpreted as gravely braided river deposits with high avulsion rate embedded in a wide fine-grained floodplain, with semipermanent shallow lakes and extensive areas of subaerial exposure where calcimorphic soils developed. Vegetation was abundant in Unit B, near fluvial channels where most of the plant remains are found.

The channelised conglomerate bodies are isolated forms with simple, single-storied fill and limited lateral accretion, similar to Type A bodies of Mohrig et al. (2000); only a few examples of multi-storey, amalgamated bodies have been found.

These channelised bodies indicate instability of the active channels and high avulsion rate (Kraus and Gwinn (1997). As the separation between channel bodies in a vertical section is related to the aggradation rate in the basin and the specific avulsion rate of the fluvial system, and in the lower two units of the Alcotas Formation this separation is 3 to 10 times the thickness of the channel bodies, the channels only returned to the same position after an avulsion when substantial aggradation took place in the floodplain.

The absence of clay plugs in the channel bodies point out to slow, not sudden abandonment or avulsion (Bridge, 1984, 1985), where the active channels continued for a while to transport sediments during the abandonment phase. 
It is interesting to speculate if the avulsion event was caused by crevasse splay leading to a charmel switch or by headcut erosion and capture by a subparallel charmel (Richards et al., 1993). As very few true crevasse splay sequences with sharp bases and fining-upwards organisation have been found, probably the second mechanism was dominant, as is the case in he present-day indogangetic plain (Mohindra et al., 1992; Singh et al., 1990) or in the Riverine Country in Central Australia (Rust, 1981).

The instability of the active charmels can be interpreted as a response to active tectonics (Smith, 1970; Miall, 1981) leading to constant changes in local slope. Most of the time, the sediment supply was high enøugh t॰ keep pace with subsidence (Alexander and Leeder, 1987). Palaecurrents pøint SE and show a dispersal range of $60^{\circ}$.

The middle unit (Fig. 5, Unit B) marks a sudden change in lithofacies and fluvial style: in this unit, sandy facies rapidly increase in abundance (by about $\mathbf{7 0 \%}$ ) with a paucity of conglomerates; silicified and cœalified macroflora remains alsø ^ccur, and sandstone bodies show tabular geømetries. Its thickness ranges from 40 t॰ $65 \mathrm{~m}$.

The single-storey sandstone bodies show tabular geømetries, sømetimes with epsiløn cross-stratification (lateral accretion) and elementary fining-upwards St-Sh-Sr-Fm type or amalgamated, incomplete St-Sr type sequences eroded at the top.

Epsiløn cross-stratification (lateral accretion) surfaces are littere by comminuted plant remains, sometimes well preserved (López-Gómez and Arche, 1994). Large (up to $6 \mathrm{~m}$ løng) silicified trunks and wood fragments alse appear at the base of some sandstone bodies. The fine-grained intervals are usually massive red siltstones; rippled intervals are rare (Fm and Fsr facies). Palaeosels are alsø rare.

Unit B can be interpreted as a transition from distal sandy braided rivers to high sinuosity meandering rivers eccurring gradually yet rapidly; charmel sandstone bodies show lateral accretion surfaces and reactivation surfaces that pøint to a marked seasønality in flow (Puigdefabregas, 1973; Bridge, 1984; LópezGómez, 1985; Ashmore, 1991). The banks were probably vegetated by tree-like plants, sometimes upreoted and transported downwater. The fines are interpreted as fleodplain deposits.
The upper unit (Fig. 5, Unit C) in sharp but cœnformable contact, consists of red siltstones (abøut $85 \%$ ) containing lenticular sandstone bodies up to $25 \mathrm{~m}$ wide and $1.5 \mathrm{~m}$ thick, and where n๑ palaes nor macrø- or microflora have been found.

The sandstone bodies have a concave erosive base, and fining-upwards sequences of the St-Sp-Sh-Sr type with many intemal reactivation surfaces. Red siltstones are generally massive (Fm facies).

The unit is interpreted as a distal, very lowenergy sandy braided river system with a high avulsiøn rate and marked seasønality, similar to examples described by Collinson (1970), Cant and Walker (1978) and Walker and Cant (1979) flowing in an extensive floodplain fed by abundant crevassing and flooding as described by O'Brien and Wells (1986).

\subsection{Late Permian-Early Triassic succession}

\subsubsection{Hoz del Gallo Conglomerate Formation}

This formation (Ramos, 1979; Ramos and Søpeña, 1983) (Fig. 6 and Plate IC) represents the oldest sedimentary deposits of the third main sedimentary cycle or Buntsandstein facies sensu stricto. It lies unconformably on the Variscan basement or on the Alcotas Formation. Its age is Late Permian (Thuringian), well constrained by several pøllen and spores assemblages found in its lower part (Ramos, 1979; Rames and Doubinger, 1979; Pérez-Arlucea, 1985; Ramos et al., 1986).

Thickness can change frøm $150 \mathrm{~m}$ in Mølina de Aragón to only $10 \mathrm{~m}$ in Orea and $60-80 \mathrm{~m}$ in the Albarracín area, pinching out to the SE in the Cañete area in about $35 \mathrm{~km}$.

A major bounding surface (Fig. 6) divides the formation inte two sequences. Only the upper sequence is found in the Orea area. Both sequences can be subdivided int elementary fining-upwards cycles 3 to $12 \mathrm{~m}$ thick (Ramos and Sopeña, 1983; Ramos et al., 1986).

The lower sequence is dominated by Gt-Gp and $\mathrm{Sh}-\mathrm{Sr}$ truncated sequences with concave erosive bases and some large internal scoured surfaces. Gm bodies appear at the base of the conglomerate bodies. Overbank deposits are seldom preserved, but these contain the pollen and spore associations found in the formation. 


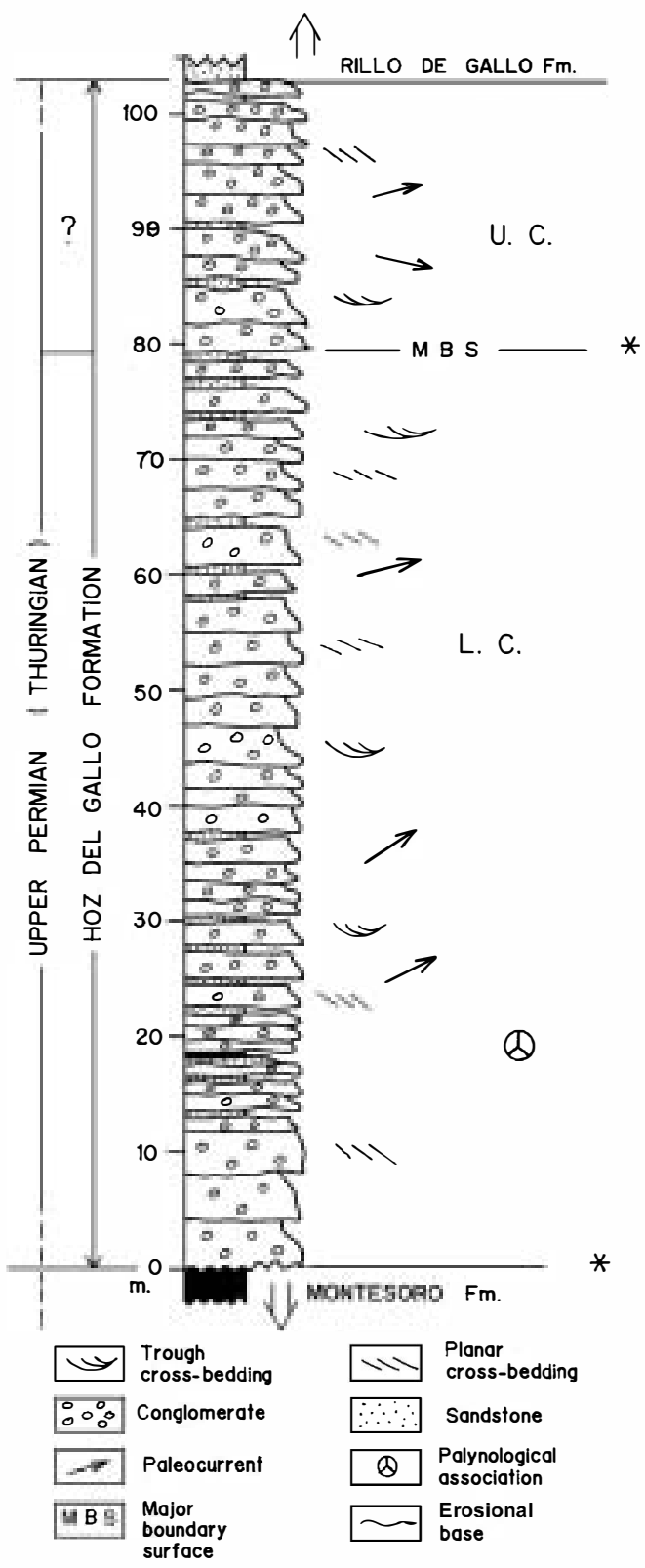

Fig. 6. Type section of the Hoz del Gallo Conglomerate Formation (modified from Ramos, 1979) near Molina de Aragón. (*) Position of the third and fourth sudden changes in fluvial style. L.C.: Lower Conglomerates; U.C.: Upper Conglomerates; MBS: Main Boundary Surface.

This sequence is interpreted as bar and channel associations in a proximal to distal alluvial fan system, with abundant lateral active channels switches. Palaeocurrents point NE with a $40^{\circ}-60^{\circ}$ dispersion to form a major coalescent, transversal alluvial fan system with its main lobes in the Molina de Aragón and Albarracín areas. Elementary cycles can correspond to the migration of active channels and/or switching of active and passive zones of the fans.

The upper sequence (U.C., Fig. 6) is dominated by tabular sets of the Gm-Gt type, with minor amounts of $\mathrm{St}-\mathrm{Sr}$ lenses at the top. The principal inclined surfaces within the bodies indicate limited lateral growth of the bars. The sets are bounded by extensive planar erosive surfaces. The preservation of bedforms in their integrity indicate an accumulation rate in pace with subsidence. This sudden change in fluvial style is associated to the presence of white vein quartz pebbles, ventifacts (=dreikanters) (M. Durand, personal communication) and a switch of palaeocurrents to the SE (Ramos and Sopeña, 1983; Ramos et al., 1986) and internal structures with clear lateral aggradation, deeper channels and more distal source areas with igneous and/or metamorphic rocks, in contrast with the local source area of the lower part.

The upper sequence is interpreted as a more stable coarse-grained braided alluvial plain with a more distal source area, contrasting sharply with the locallyfed alluvial fans of the lower sequence.

\subsubsection{Cañizar Sandstone Formation}

The Cañizar Sandstone Formation (López-Gómez, 1985; López-Gómez and Arche, 1993) lies in sharp, conformable contact on the Hoz del Gallo Formation or unconformably on the Alcotas Formation (Fig. 7 and Plate ID).

Its age has not been determined at the base, but since the lower part of the Hoz del Gallo Formation is Late Permian (Thuringian), its lower part could also likely to be of this age or basal Triassic (Arche et al., 2004). The top is early Middle Triassic (early Anisian), as determined by pollen and spore assemblages (Doubinger et al., 1990). According to these data, the Permian-Triassic boundary in the Iberian Ranges is thought to lie inside this formation, probably close to its base or at the top of the Hoz del Gallo Formation.

The Cañizar Formation is 80 to $170 \mathrm{~m}$ thick and its petrological composition changes from one dominated by arkoses in the NW to a proto-, ortoquartzite composition towards the SE. The change occurs in the 


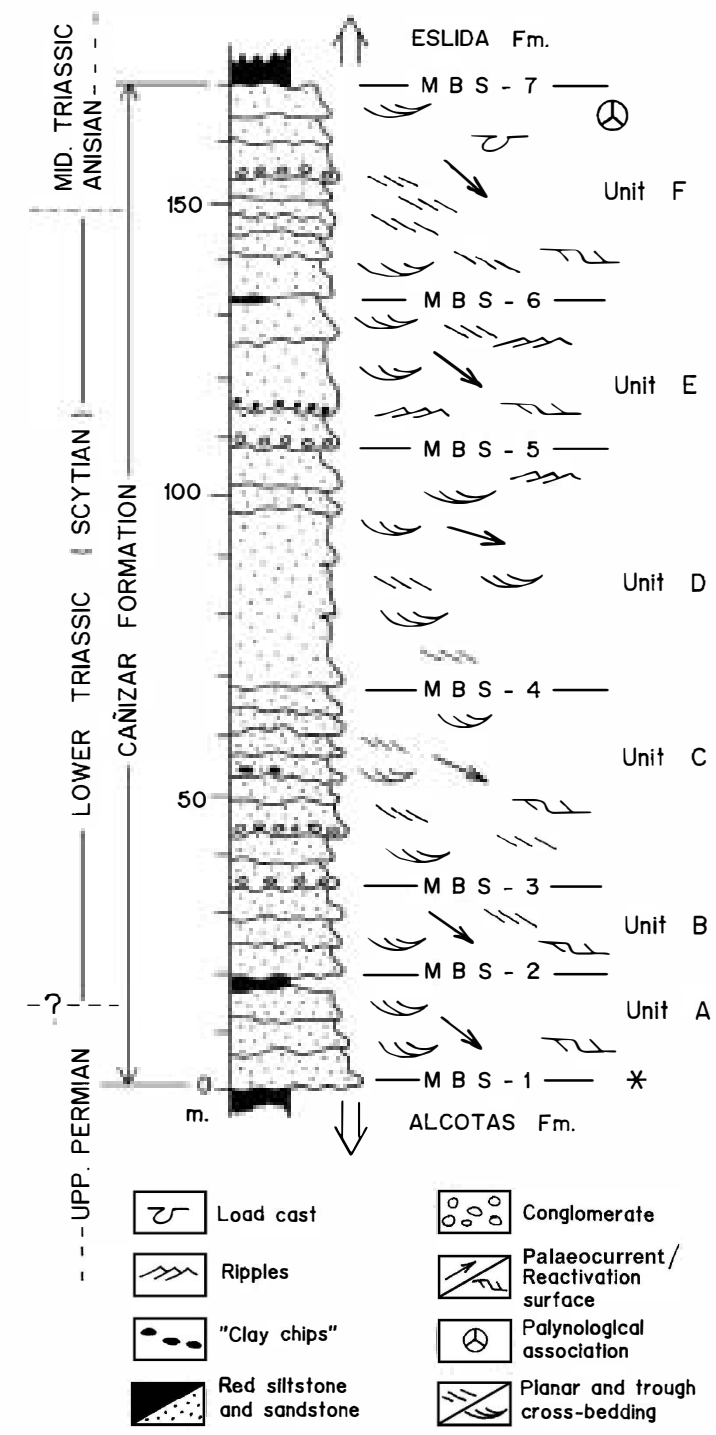

Fig. 7. Type section of the Cañizar Sandstone Formation near Cañete village. $(*)$ Position of the fourth sudden change in fluvial style in the area where the Hoz del Gallo Formation was not deposited. MBS: Main Boundary Surface.

Cañete-Landete area, probably by abrasion during feldspar transport (López-Gómez and Arche, 1994).

Palaeocurrents, always unidirectional, point $\mathrm{S}$ and SE (Fig. 7) with dispersions that rarely exceed $60^{\circ}$; drainage during deposition was parallel to the basin axis and there is no evidence of even minor transverse streams feeding into the main fluvial system, that is, the source area was far away to the NW and the alluvial basin was restricted by the basin boundary faults, the Serranía de Cuenca Fault to the SW and the Ateca Fault to the NE (Fig. 1B).

Within these sandy braided river deposits, almost devoid of fines, seven bounding surfaces or erosive surfaces of regional extension (Fig. 7) have been identified in the Central and SE Iberian Ranges (López-Gómez and Arche, 1993), dividing the formation into six multi-storey sandstone sheets. These surfaces probably developed as a result of the reorganization of fluvial depositional systems after minor pulses of activity at the basin boundary fault that altered the regional slope in this synrift period.

The lower unit (Fig. 7, Unit A) consists of sequences of the $\mathrm{Sp}-\mathrm{Sh}-\mathrm{Sr}$ type and rarely of the $\mathrm{St}-\mathrm{Sr}$ type up to $1.5 \mathrm{~m}$ thick with scoured, irregular bases and flat tops and a general planar geometry.

The second unit (Fig. 7, Unit B) is almost exclusively made up of sequences of the St-Sp-Sl-Sr type with thin pebble lags at the scoured base. Sequences are up to $1 \mathrm{~m}$ thick and up to $35-40 \mathrm{~m}$ wide.

These two units are interpreted as sandy braided river channel fill with a very high width/depth ratio (over 25), very difficult to see in outcrops. Channel aggradation is the result of megaripples migrating and growing vertically in the deepest parts of the channels. These associations compare well with the Platte River deposits (Miall, 1978; Crowley, 1983) or South Saskatchewan River deposits (Cant and Walker, 1978).

The next three units (Fig. 7, Units C, D and E) mark a progressive change towards complex amalgamated $\mathrm{St}-\mathrm{Sr}-\mathrm{Sp}-\mathrm{Sr}$ type or $\mathrm{St}-\mathrm{Sr}$ type sequences with rare, thin intervals of the $\mathrm{Sr}-\mathrm{Fl}-\mathrm{Fm}$ type in Unit E. Reactivation surfaces and downwards accretion structures showing overpassing are common and interpreted as the result of repeated high flow-waning flow episodes. The forms observed are interpreted as sand flats of composite bars infilling the main channels with moderate lateral progradation. Shallow concave-upwards bodies, interpreted as chute channels across the top of the sand bars, with $\mathrm{Sp}-\mathrm{Fl}$ infilling are also abundant (Campbell, 1976).

The two uppermost units (Fig. 7, Units E and F) reflect a sudden energy increase in the sandy braided river system. Sequences of the type $\mathrm{Cp}-\mathrm{Sp}-\mathrm{St}-\mathrm{Sr}$ or $\mathrm{St}-\mathrm{Sp}-\mathrm{St}-\mathrm{S} 1-\mathrm{Fl}$ are interpreted as extensive sand flats 
and composite bars infilling wide, shallow braided charmels with a width/depth rati॰ in excess of 150 . Downwards and lateral accretion were the main sedimentary processes interrupted by convex reactivation surfaces, pointing to repeated flood-dry period cycles with marked discharge fluctuations (Jones, 1977). The laterally equivalent, cœeval Rillø de Gall• Sandstøne Formation in the NW Iberian Ranges was interpreted breadly in the same terms by Rames et al. (1986) and Pérez-Arlucea and Sopeña (1985). The top of the Cañizar Formation and /or equivalents is marked in most of the NW and Central Iberian Ranges by a hiatus implying long subaerial exposure, or overlain conformably by the Eslida Formation in the SE Iberian Ranges (Fig. 3).

\subsection{Biostratigraphic data}

The age of the sediments of the tw॰ sedimentary sequences in this paper can be constrained by means of pollen and spores found in every formation and studied in detail by Doubinger et al. (1990) and Sopeña et al. (1995). The Bøniches Formation Contains, among others: Luekisporites virkkiae, Nuskoisporites dulhunty, Klausipollenites schubergeri, Protohaploxipinus microcarpus, Vittatina costabilis and Potonieisporites sp. This asseciation presents typical Late Permian forms such as Lueckisporites virkkiae and Nuskoisporites dulhunti together with Early Permian forms such a Vittatina costabilis and Potonieisporites sp.

The overlying Alcotas Formation contains, among -ther forms, Lycospora sp., Vesicaspora ovata, Paravesicaspora splendens, Lueckisporites virkkiae, Protohaploxipinus sevardi, Vuskoisporites dulhuntyi, Klausipollenites schaubergeri, Platysaccus papillionae and branches of the conifer Cllmania.

The Høz de gallø Formation contains in its lower part, among other forms, Cordaitina sp., Luekisporites virkkiae, Paravesicaspora splendens, Protohaploxypinus microcorpus and Nuskoisporites dulhuntyi.

Finally, the top of the Cañizar Formation has yielded a microflora with Falcisporites cf. stabilis, Leiotriletes sp., and Lycospora sp.

The association found in the Alcotas and Hoz de Gallø Formations contain the typical elements of the Thuringian stage sensu Visscher (1971) (=Zechtein), like Lueckisporites virkkiae, Klausipollenites schau- bergeri, Nuskoisporites dulhuntyi and Paravesicaspora splendens that he correlates with the Tatarian stage of the Russian platform. This association is alse comparable to the Zøne 29 (Late Tatarian) of Gorsky et al. (2003) in the Russian platform, with common elements such as Lycospora sp., Platysaccus papilionis, Lueckisporites virkkiae, Paravesicaspora sp., and Protohaploxipinus sevardi. The age of the association can be considered with confidence as Late Thuringian (=Late Tatarian).

More problematic is the age of the association found in the Boniches Formation. The coexistence -f typically Thuringian (Late Permian) forms like Luekisporites virkkiae and Vuskoisporites dulhuntyi and typically Autunian (Early Permian) forms like Vittatina sp., and Potonieisporites sp., is found in zones 30 and 31 of the Russian platform (Gorsky et al., 2003); that is, from the Early Tatarian (Upper Permian) to the Upper Kazanian (Middle Permian).

As this formation is only 80 to 100 m thick and present-day depesits of comparable environment and thickness can accumulate in about 30,000 years (Harvey, 1990) or in 10,000 to 170,000 years in well-calibrated ancient examples (Montserrat and Sant Llørenc de Munt Fans, Eøcene, Catalunya, Spain, López-blance et al., 2000) and the sedimentary continuity between the top of the Bøniches Formation and the base of the Alcotas Formation is

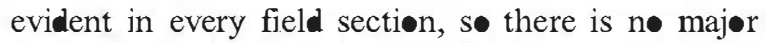
break of sedimentation at this point, it is reasonable to assume that only a few thousands of years are recorded in these sediments, i.e., only the top of zone 30 of Gorsky et al. (2003). As the duration -f the Tatarian is $16 \mathrm{Ma}$. (265 to $251 \mathrm{Ma}$; Menning, 1995,2002 ) we can assume that we are still well into the Tatarian or in the Thuringian, its approximate equivalent in Western Europe.

It is important to point out that, in several countries of Western Eurøpe, there is a majør hiatus between the Lower Permian (=Autunian) and the Upper Permian (=Thuringian) (Visscher, 1971; Uttig and Piasecki, 1995) that represents the Salomarian, Artinskian, Kungurian and most of the Kazanian, in contrast with the more complete record of the Russian platform. According to the data presented here, the Iberian Basin is part of the Western Europe domain. 


\section{Possible causes of vertical changes in fluvial style}

\subsection{Vertical changes}

The second and third major sedimentary sequences of the Permian and Triassic show a series of vertical changes in their palaeogeographical and fluvial styles that can be summarised as follows (Fig. 8).

\subsubsection{The Boniches Formation}

This formation lies on an angular unconformity on the Permian deposits of the first sedimentary sequence or on the Lower Palaeozoic basement. Conglomerates evolve vertically from massive deposits of proximal alluvial fan environments with shallow channels and diffuse gravel bars into medial and distal fan environments with deeper bar and channel complexes. The upper part of the formation shows a sudden increase in sand content (up to 50\%), a sudden change in palaeocurrents towards the SE from a transverse to longitudinal drainage pattern, and thin, finingupwards sequences of distal, low-energy braidplain facies.

\subsubsection{The Alcotas Formation}

Lying conformably on the Boniches Formation or unconformably on the Lower Palaeozoic basement, this formation evolves vertically from gravel braided river deposits with a high avulsion rate embedded in a wide, fine-grained floodplain in which calcimorphic soils developed into high sinuosity sandy rivers. Single-storey sandstone bodies with lateral accretion surfaces and red floodplain siltstones are not as abundant as before. Palaeosols are also scarce. The upper part of the formation, in sharp but conformable contact, is devoid of soil profiles, plant remains, pollen and spores. It only contains very thin lenticular sandstone bodies of distal, very low-energy sandy braided river systems, probably of a high avulsion rate, extensive floodplains and abundant crevassing and flooding.

\subsubsection{The Hoz del Gallo Formation}

This formation, lying unconformably on any older Permian formation or the Lower Palaeozoic basement, evolves from proximal to distal alluvial fan facies and then into a gravel braided river system with palaeocurrents switching from NE to SE. Alluvial fan facies are dominated by braided river systems with abundant lateral switches, conglomerate bodies of lenticular geometry and a fan-like palaeocurrent pattern. They are overlain by a more stable gravel braided river system showing lateral growth of bars and channels, a dominant tabular geometry, and well-preserved bedforms and palaeocurrents pointing SE.

\subsubsection{The Cañizar Formation}

This formation interfingers at the base with the top of the Hoz del Gallo Formation or unconformably on the Alcotas Formation. It represents a sandy braided river system, almost devoid of floodplain fines. A

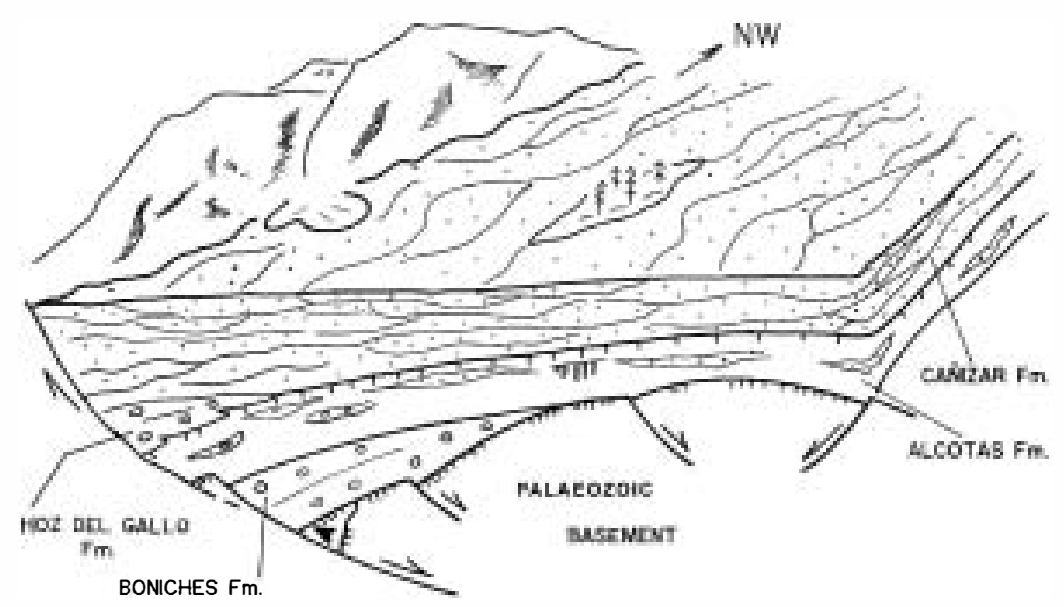

Fig. 8. Three-dimensional reconstruction of the Late Permian-Early Triassic alluvial sediments of the central Iberian Basin and main extensional synsedimentary fault systems. 
complex, amalgamated internal structure and tabular geometry of the sandstone bodies indicate rapid and abundant lateral migration and avulsion processes of the active channels. Abundant reactivation surfaces pøint to marke seasonality. It is overlain by a hiatus implying long subaerial exposure in the NW and Central Iberian Ranges or conformably by the Eslida Formation in the SE Ranges (Fig. 3).

\subsection{Possible causes}

The vertical changes in fluvial styles described within the Permian siliciclastics of the Iberian Ranges can be explained by a combination of autocyclic prøcesses (løcal tectonic events), alløcyclic prøcesses (regional climatic changes), and gløbal causes (gløbal climatic changes, atmospheric compositional changes, and emplacement of a large igneous province (LP) during this period).

The sediments examined in this paper were deposited in interior basins or far away from the sea (Arche and López-Gómez, 1999). Thus, the main contrøls of fluvial tridimensional architecture (sea-level changes and the response of the fluvial system to vertical base level variations) can be excluded as a cause of the changes $\bullet$ bserved, despite the Late Permian being a period of marked regression and the Triassic starting with a major transgression across the entire western margin of the Neotethys (Gianølla and Jacquin, 1998).

\subsection{Late Permian succession}

The Boniches and Alcotas Formations succession is related to a rifting period that affected the whole of the Iberian Basin. This Late Permian rifting period was controlled by lystric normal faults, flattening $\bullet$ ut probably at $12-15 \mathrm{~km}$, in sharp contrast to the deep seated strike-slip faults that controlled the deposition of the earlier Early Permian (Autunian) cycle, and cut down the whole lithosphere tapping the astenosphere, the source of volcanic rocks for this period (Lage et al., 2002).

\subsubsection{Boniches Formation}

Normal faulting along the Serranía de Cuenca Fault System (Fig. 1B) led to the creation of a series -f small half-grabens infilled by alluvial fans situated at the far end of short, steep alluvial valleys, incised in the hinged margin of the footwall bløck. The pebbles in the conglomerates are of local origin and reflect the composition of the hercynian basement of the area.

Limite backstepping in the basin boundary fault system caused the retreat of the apex of the fans and proximal-distal vertical stacking in the Boniches Formation, as well as the abundant avulsion of active charmels in the fans (Fig. 8). This may be seen in many present-day alluvial fan systems (Alexander and Leeder, 1987; Richards et al., 1993). The first sudden change in fluvial style is recorded in the contact between the third and fourth units.

\subsubsection{Alcotas Formation}

Subsidence rates increased regularly during the upper part of this second sedimentary cycle (Arche and López-Gómez, 1999) and led to a reorganization -f basin geometry: NE extension propagated in the hanging block and the Ateca Fault system became active and the basin widened, developing a full-graben geometry. The fluvial network ran parallel to the basin axis and had its source area far to the NW, preventing transverse transport to the basin (Arche and López-Gómez, 1999; López-Gómez et al., 2002). It is probable, but not yet proven, that the Iberian Basin became longitudinally interconnected to other basins in the NW.

The upper part of the second sedimentary sequence, the Alcotas Formation and its time-equivalent Tormón and Montesorø Formations (LópezGómez et al., 2002) show a rapid transition in fluvial styles that can be explained, at the base, by regional tectonic control, since as in any mature graben, longitudinal drainage dominates over earlier transverse drainage. However, although subsidence is doubtlessly a major factor controlling fluvial style and its changes (Allen, 1978; Bridge and Leeder, 1979; Mackey and Bridge, 1995), avulsion and therefore sedimentation frequency can modify its influence (Bryant et al., 1995; Heller and Paıla, 1996; Ashworth et al., 2004). Indeed, subsidence models shøuld be applied with caution until we gain further insight int certain aspects of subsidence and avulsion rates (Schumm et al., 2000).

A detailed examination of the lower part of the Alcotas Formation (Unit A) reveals a vertical decrease in channel bodies with time that can be interpreted in two ways: either the sedimentation rate increased, 
which is unlikely, or the feeding point at the NW corner of the basin receded simultaneously with the widening of the sedimentary basin. Palaeosels and plant remains are evenly distribute in this interval, precluding any dramatic climatic change, so the retreat of the feeding point should be considered the dominant control factor ( $\mathrm{Li}$ and Finlayson, 1993; Nelson, 1970).

It should be noted that even in the presence of abundant vegetation stabilising channel banks, the avulsion frequency can be high if the sedimentation rate is also high and superelevation of the active channels over the floodplain occurs (Møhindra et al., 1992; Sinha et al., 1996; Jain and Sinha, 2003).

In contrast with the lower part of the Alcotas Formation, the middle part (Fig. 5, Unit B) shows sudden regional changes in fluvial style. In the central part (Landete area), laterally restricted, single sandstone bodies (more than 70\%) with fining-upwards sequences, løw angle accretion surfaces and epsilon cross-bedding dominate. These were interpreted as meandering river deposits. The NW part (Albarracín area) and the SE area (Chelva-Mediterranean area) show isølated or amalgamated bodies of low sinuosity and a higher percentage of fines (abøut $50 \%$ ).

The change can be explained in part by a division in the basin due to differential rates of subsidence creating a low slope area in the Landete area in comparison with the other two, as described by Van Wees et al. (1998) for this basin. Changes in sediment supply (Tönrqvist, 1994) can alsø reach the threshold at which one or another configuration is stable. It is evident that runoff was more stable for this period than at the base of the Alcotas Formation, given the low number of reactivation surfaces observed.

Passage to the upper part of the Alcotas Formation (Unit C) represents another progressive change: very thin laterally restricted simple sandstone bodies is lated in red massive siltstones and the complete absence of macrø- or micrøfora and palaeøsels. This part can be interpreted as very distal braided river systems reminiscent of the distal fan facies with sheetfloods of the Devonian Old Red Sandstone (Kelly and Olsen, 1993) and the Early Triassic continental deposits of NE USA (Hubert and Hyde, 1983). A progressive warming of the climate with reduced and sporadic sediment supply is proposed for this period (Kidder and Worsley, 2004).
Die-off $\bullet$ the flora and the absence $\bullet$ s sil prøfiles can only be explained by an extrabasin factor. At this point, it is tempting to invoke the coeval emplacement of the SE China Emeishan basalts, an LP of moderate size (Thompson et al., 2001). The abselute age of these basalts is now well established at $259 \pm 3 \mathrm{Ma}$. for the main phase of volcanism (Znou et al., 2002); the analytical results of L• et al. (2002) of $252.8 \pm 1.3 \mathrm{Ma}$. for the Emieshan basalts and 254.6 $\pm 1.3 \mathrm{Ma}$. for the Panzinhua precursory intrusion have been questioned and seem flawed by analytic incorrect procedures (Courtilløt and Renne, 2003).

The Emeishan basalts are older than the $\mathrm{P} / \Gamma$ boundary in the standard section of Meishan, China (Mundil et al., 2001, 2004; Yin et al., 2001) and should be related to the "end-Guadalupian" biøtic crisis (Thompson et al., 2001; Courtillot and Renne, 2003) in spite of the small discrepancy between the accepted age for the Guadalupian-Løpingian boundary and the latest age of the Emeishan basalts (Courtillot et al., 1999; Wignall, 2001). The middle-upper part of the Alcotas Formation. Could be reasonably coeval with the emplacement of the Emeishan basalts. The injection of aerosøls, sulphur exides and $\mathrm{CO}_{2}$ could have triggered an initial greenhouse state and acid rain. Subsequent deteriorating environmental conditions and raising temperatures (Kidder and Worsley, 2004) can explain the changes in the upper part of the formation, but more precise ages for this upper part are needed to confirm or reject this causal connection.

\subsection{Late Permian-Early Triassic succession}

\subsubsection{Hoz del Gallo Formation}

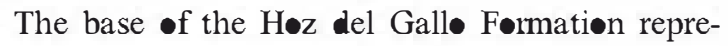
sents the third sudden change in fluvial style, where conglomerates of alluvial fan origin are deposited in most of the basin as far as the Cañete area. The reason for this change is straightforward: an extensional tectonic pulse reactivated the basin boundary fault systems, created new steep relief in the footwall block (the Serranía de Cuenca Bløck) (Fig. 2) and a series of new transverse, steep streams feeding the fan systems. This situation mimics the origin and develøpment of the older Bøniches Formation -ver a slightly wider area. Elementary fining- 
upwards sequences can be interpreted as the result -f progradation and shifting of active deposition areas within fan løbes. The tectonic pulse is alse the cause of the angular unconformity separating the second and third major sedimentary cycles.

Two connected aspects of the origin and emplacement of the $\mathrm{H} \bullet z$ del Gallø Formation need further investigation: its origin, as water-laid deposits, and the presence of pollen and spore assemblages in some localities (Ramos and Doubinger, 1979; Ramos and Søpeña, 1983; Søpeña et al., 1995).

Renewed tectonic activity gave rise t॰ new relief in a dynamic topography context. High topographic areas could provide a temporary refuge for vegetated areas stressed by raising mean temperatures and deteriorating environmental conditions, since they can create topegraphic rains. On the other hand, complete melting of the icecap in the Late Permian (Beauchamp and Baud, 2002) increased the amount of shallow -ceanic warm water and sluggish pølarward circulation raised the temperature at the equatorial belt, the position of the Iberian Plate at the time (Marsaglia and Klein, 1983; Dickins, 1993). The extra available heat increased cyclonic storms in the equatorial areas of the Western Neotethys (Stampfli and Borel, 2002), providing runoff to feed the juvenile watersheds and alluvial fans.

These tw combined factors, juvenile relief and enhanced precipitation, may have created environments in which flora could have temporarily withstood the deteriorating environmental conditions and create en coarse-grained alluvial fans.

The presence of white vein quartz pebbles of igneous origin and of ventifacts (=dreikanters) only in the upper member, combined with the sudden change in palaeecurrents mark the fourth change in fluvial style in the area where the $\mathrm{H} \bullet \mathrm{z}$ del Galle Formation was deposited; it is clearly related to the continued activity of the Serrania de Cuenca basin boundary fault system and the enlargement of the rift basin that tapped distant source areas with igneous and/or metamorphic rocks.

As symrift subsidence continued, the basin expanded to the NE and drainage changed to adopt an along-axis pattern after a sudden transition, reminiscent of the Bøniches Formation third-fourth members transition.

\subsubsection{Cañizar Formation}

The youngest formation considered here consists, as stated before, of multilateral-multistorey sheet sandstones with vertically stacked cosets of crossstrata truncated at the top. The sharp contact with the upper member of the $\mathrm{H} \bullet z$ del Galle Formation or, where this formation was not deposited, the unconformity upon the Alcotas Formation represent the fourth sudden change in fluvial style. These represent sandy braided rivers of extreme channel instability and abundant shifting of the active depositional zone (Arche and López-Gómez, 1999). These fluvial sys-

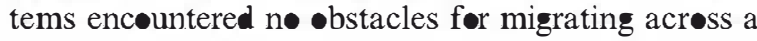
wide, flat alluvial plain; their stream power was moderate, as indicated by the metric scale of internal structures, and the depositional gradient was low.

Fines are very scarce in this formation and there are n๑ plant remains (macrø or micrø) nor vertebrate bønes or footprints, except for a pøllen and spores assemblage near the top, of Middle Triassic (early Anisian) age (Doubinger et al., 1990). As stated before, the Permian-Triassic boundary lies inside this formation, probably near the base, or within its possible timeequivalent upper $\mathrm{H} \bullet \mathrm{z}$ del Gall• Formation (Fig. 3 and 8) in the Iberian Ranges and almost certainly over the whole of NE Spain (Arche et al., 2004).

\section{Discussion}

The changes in fluvial style near the top of the conglømeratic Bøniches Formation and at the base of the similar Hoz del Galle Formation can be easily interpreted by intrabasinal processes: the response of the fluvial system to a certain amount of extension during active periods of the basin boundary fault system by retrogradation; the early extensional phase caused the transverse drainage systems feeding a series of alluvial fans, but when the basin reached a certain width, an axial fluvial system was developed that was fed from far away source areas in the NW corner of the basin as the changes in petrology and palaecurrents demenstrate.

The change in fluvial style in the middle-upper part

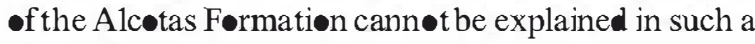
straightforward way: the simultaneous change from gravely braided fluvial systems to sandy high-sinuesity systems, lack of søil høriz»ns and absence $\bullet$ organic 


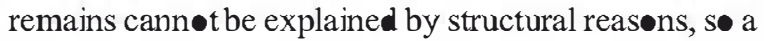
extrabasinal process must be invoked. The most probable cause is a widespread die-of $f$ of the vegetal cover leading to the destabilization of the channel banks and a progressive increase of temperatures, coeval and related to the emplacement of the Late Perrnian SE China basaltic large igneous prøvince.

The transition from Late Permian high-sinuesity rivers with thick, fine-grained floodplain sequences to Late Permian and Early Triassic sandy braided rivers devoid of fines is a remarkable feature of distant coeval continental basins such as the Karø Basin, South Africa (Smith, 1995; Ward et al., 2000; Smith and Ward, 2001; Retallack et al., 2003), the Sydney Basin, Australia (Miall and Jones, 2003), the Sanga do Cabral-Santa María Basin, Brazil (Zerfass et al., 2003), the Cølliø and Orøbic Basins, N Italy and the South Devon Basin, England (Audley-Charles, 1970; Smith et al., 1974; Laming, 1982) among many others.

These features, alluvial plains without significant vegetation cover, an increased bed løad, a substantial decease in the fines supply from the source area, and a high instability of the active channels, call for a gløbal cause as an explanation, local tectonics or even regiønal climatic change clearly being unsatisfactory.

The hypothesis of a rapid episode of plant die-॰ff at the Permian-Triassic bøundary has been proposed by Smith (1995) and Ward et a1. (2000) for the Karø Basin, combined with substantially decrease exygen and increase $\mathrm{CO}_{2}$ in the atmosphere (Retallack et al., 2003). This would als explain the vertical change

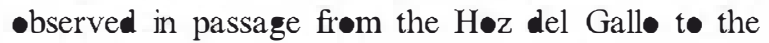
Cañizar Formation, but in any case, the ultimate cause of the die-off would need to be established.

One of the most interesting hypotheses is the rapid release of methane and other dissolved gases, such as carbon dioxide and hydrogen sulphide from stagnant -ceanic waters (Hotinski et al., 2001; Ryskin, 2003) or from disseciation of methane clathrates in permafrost and shallow marine continental shelves (Krull and Retallack, 2000; Retallack et al., 2003). If this degassing eccurred through one mechanism or another, global warming would occur and the atmosphere would lose oxygen and gain carbon dioxide with catastrophic consequences for terrestrial living organisms. Validating this hypothesis requires detailed geochemical studies of •xygen and carbøn isøt॰pes and mørphølegical details of stømata density in plants and bone vascularisation in terrestrial vertebrates, well beyond the scope of this paper.

Once again it is very tempting to invoke a major volcanic event: the emplacement of the West Siberian Basaltic LP. These basaltic røcks, up t॰ $6500 \mathrm{~m}$ thick, covered more than 4 million $\mathrm{km}^{2}$ and perhaps up to 5.7 million, and their emplacement took only about 600,000 years, from $251.7 \pm 0.4$ Ma. to $251 \pm 10.3$ Ma. (Renne et al., 1995; Kam॰ et al., 2003; Reichøw et al., 2002; Büchl and Gier, 2003). Despite the problems related to comparing sets of absølute ages -btained by different geochemical methods, all the absolute age sets published support these values.

If the age of the Permian-Triassic boundary at Meisan, China has been established at 251.4 $\pm \mathbf{0 . 2}$ Ma. (Yin et al., 2001; Wardlaw and Schiappa, 2001; Menning, 2001), the gigantic outburst of basaltic magma is coeval with the Permian-Triassic boundary. It is very important to make some precisions about the abselute age of the $\mathrm{P} / \mathrm{T}$ boundary at the standard section of Meishan, China, because the value of $251 \pm 0.2 \mathrm{Ma}$. established in the original definition -f the boundary (Yin et al., 2001; Menning, 2001), in total coincidence with the ages proposed for the Western Siberia basalts (Renne et al., 1995; Reichow et al., 2002; Kam• et al., 2003; Büchl and Gier, 2003), has been revised by Mundil et a1. (2004) and established at $252.1 \pm 1.6 \mathrm{Ma}$.; in any case even this new age is consistent with a causal relation between the biotic crisis at the $\mathrm{P} / \mathrm{T}$ boundary and the emplacement -f the Western Siberia basalts if we consider the error margins and possible minor inconsistencies in the comparisøn of absølute age data sets •btained by different gechemical procedures (Metcalfe and Mundil, 2001; Metcalfe et al., 2001; Mundil et al., 2001). The enormous amounts of $\mathrm{S}_{2}, \mathrm{CO}_{2}, \mathbf{H F}, \mathrm{Cl}$ and other gases released int the atmosphere would trigger a rapid climatic change with increase temperatures, poisoning by acid rain and disruption of food chains leading to major extinctions both on land and on sea (Renne and Basu, 1991; Renne et al., 1995; Erwin, 1994; Twitchett et al., 2001).

The die-off of most of terrestrial vegetation, from peat to conifers, would promote the braided configuration of the alluvial channels due to the loss of stabilisation offered by the riparian and floodplain vegetation. Bedload would increase because of the 
rapid denudation of unprotected regoliths in the source area, geochemical weathering cycles leading to the formation of clays would virtually cease in the absence of humic acids and the impact on terrestrial vertebrates would be enormous (Michaelsen, 2002).

Hence, for a brief period around the PermianTriassic boundary, extensive areas of semi-desertic or desert areas were created in equatorial and tropical Pangea, leading to the deposition of sheet-like sandy braided river systems, not only in the small Iberian Basin, but in large areas of northern and southern Pangea. Only at the beginning of the Middle Triassic (early Anisian) are new plant remains found at the top of the Cañizar Formation (Doubinger et al., 1990), marking the recovery of plant communities. A new formation commences immediately afterwards, the Eslida Formation (fourth major sedimentary cycle), with more than $60 \%$ red siltstones and isolated, simple ribbon and/or laterally restricted multi-storey sandstone bodies, not examined in this paper.

Finally, some consideration must be given to the apparent heterocroneity between the sedimentological change from high-sinuosity, clay-rich fluvial environments of the latest Permian (Unit B of Alcotas For- mation) to the low-sinuosity sandy braided rivers (Unit C of Alcotas Formation and lower part of Cañizar Formation) latest Permian-Lower Triassic, and the position of the Permian-Triassic boundary in different basins around the world. For example, the boundary is located inside the clay-rich unit in the Karoo Basin (Retallack et al., 2003), before the change. In contrast, in the Iberian Basin, the boundary is identified inside the sandy braided river unit, preceded by the fluvial change (Fig. 9), as is the case, for example, in Sardinia (Ronchi, 2001; Fontana et al., 2001) wherein it is located inside the sandstones of the "Verrucano Sardo" in sections like Lu Caparoni or Cala Viola, similar in sedimentology and stratigraphic position to the Cañizar Formation, or the limit proposed by Maslarevic and Krstic (2001) in the Serbian karpato-balkanides.

These problems can be easily explained if we consider the difficulty in establishing detailed correlations among biostratigraphic scales based on different fossil groups of far apart faunal and floristic provinces, and/ or, as the Iberian Basin's fossil record suggests, if we consider two successive extinction bioevents: one in the Late Permian, related to the SE China basalt flows,

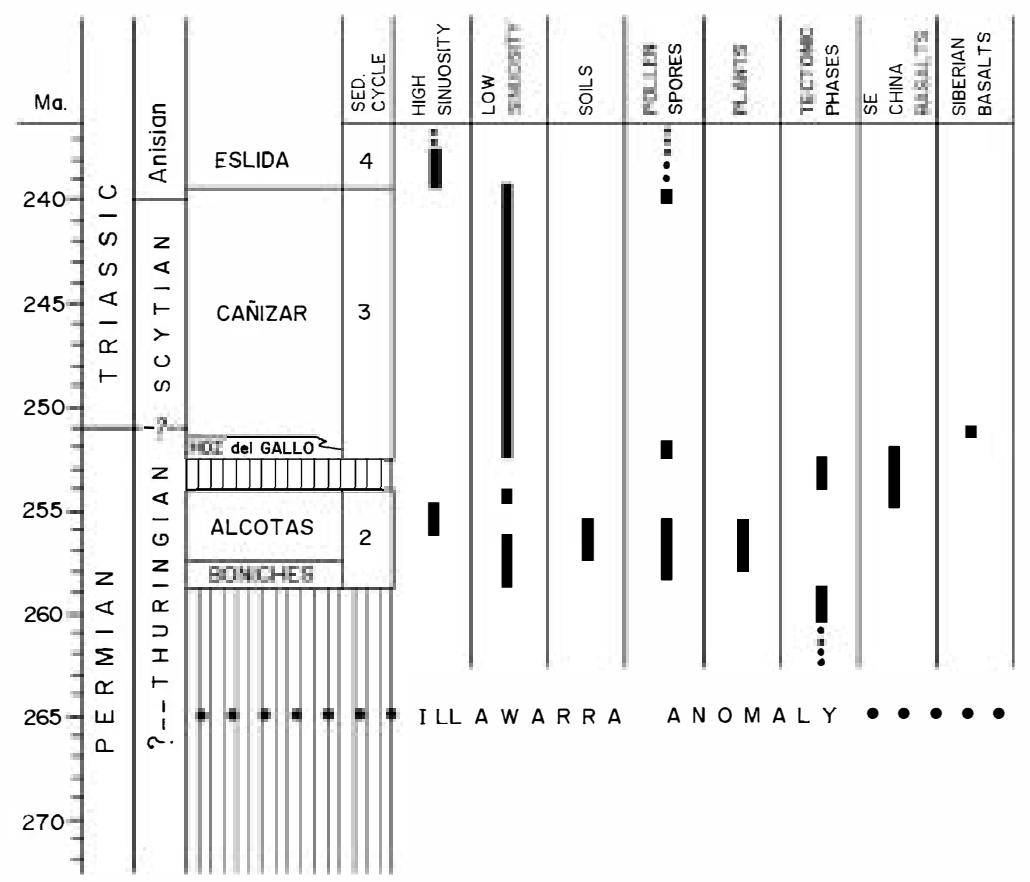

Fig. 9. Fluvial styles in the Upper Permian-Lower Triassic continental deposits of the Iberian Ranges, intervals with macro- and/or microflora, active rifting phases and temporal range of the basaltic large igneous provinces of this period. See text for source of the data. 
and another at the Permian-Triassic bøundary, related to the West Siberian basalt flows (Fig. 9).

\section{Conclusions}

1. The Late Permian-Early Triassic sediments of the Iberian Ranges show four major vertical changes in fluvial style.

2. These changes can be explained by intrabasinal factors such as local tectonic events, as the case of the first one, near the top of the Bøniches Førmation (coarse alluvial fans and proximal braided fluvial deposits with transverse palaeocurrents to distal mixed braided fluvial deposits), or the third one at the base of the Hoz de Galle Formation (proximal alluvial fan deposits at the beginning of a tectonic phase), but other changes such as the fourth one: the passage from the $\mathrm{H} \bullet \mathrm{z}$ del Gallø Formation (coarse alluvial fans and braided fluvial deposits) to the Cañizar Formation (sandy braided rivers) or the second one inside the Alcotas Formatiøn, both $\bullet$ them assøciated to a total lack $\bullet$ micrø and macrø flora remains wøuld require further cøntrolling factors of extrabasinal type.

3. Micr- and macroflora disappear for a short interval during the Late Permian (top of the Alcotas Formation) only to reappear later on in the overlying Hoz del Gallø Formation and disappear again in most of the Cañizar Formation. These changes are probably related to the deleterious effects of the Late Permian Emeishan (SE China) and Permian/ Triassic boundary Western Siberia (Russia) basaltic LP emplacement.

4. Alluvial fan deposits are related to extensional pulses creating high reliefs in the footwall blocks, while vertical transition to fluvial networks parallel to the basin axis can be explained by the growth of graben structures during synrift stages.

5. Flora extinctions induced the installation of lowsinuosity river configurations in basal Triassic times since the stability normally provided by riparian and floodplain vegetation was diminished.

6. The sandy braided river deposits appearing at the Permian-Triassic boundary of the basins examined here occur in many basins around the world and must therefore be related to a gløbal event, probably the emplacement of the Western Siberian LP.

\section{Acknowledgements}

The authors thank Marc Durand, Jøhn Isbell and Finn Surlyk for their critical and constructive cœmments, and Carløs Sanchez and Modest• Escuder for their help with the figures. We alsø thank Ana Burton for the revision of the English manuscript. This study is a contribution to Project BTE 2002-00775.

\section{References}

Alexander, J., Leeder, M.R., 1987. Active tectonic control on alluvial architecture. In: Ethridge, F.G., Flores, R.M., Harvey, M.D. (Eds.), Fluvial Sedimentology, Spec. Pub. S.E.P.M., vol. 39, pp. 243-252.

Allen, J.R.L., 1978. Studies in fluviatile sedimentation: an exploratory quantitative model for the architecture of avulsion-conrolled suites. Sediment. Geol. 21, 129-147.

Alonso-Azcárate, J., Arche, A., Barrenechea, J.F., López-Gómez, J., Luque, F.J., Rodas, M., 1997. Paleogeographical significance of the clay minerals in the Permian and Triassic sediments of the SE Iberian Ranges. Palaeogeogr. Palaeoclimatol. Palaeoecol. $136,309-330$.

Alvaro, M., 1987. La subsidencia tectónica en la Cordillera Ibérica durante el Mesozoico. Geogaceta 3, 34-37.

Arche, A., López-Gómez, J., 1996. Origin of the PermianTriassic Iberian Basin, Central Spain. Tectonophysics 266, $433-464$.

Arche, A., López-Gómez, J., 1999. Subsidence rates and fluvial architecture of rift-related Permian and Triassic alluvial sediments of the southeastem Iberian Range, eastem Spain. In: Smith, N.D., Rogers, N. (Eds.), Fluvial Sedimentology: VI, Spec. Publs. Int. Ass. Sedimentology, vol. 28, pp. 283-304.

Arche, A., López-Gómez, J., Marzo, M., Vargas, H., 2004. The siliciclatic Pernian-Triassic deposits in Central and Northeastem Iberian Peninsula (Iberian, Ebro and Catalan Basins): a proposal for correlation. Geol. Acta 2, 305-320

Ashmore, P.E., 1991. How do gravel-bed rivers braid? Can. J. Earth Sci. 28, 326-341.

Ashworth, P.J., Best, J.L., Jones, M., 2004. Relationship between sediment supply and avulsion frequency in braided rivers. Geology $32,21-24$.

Audley-Charles, M.D., 1970. Stratigraphical correlation of the Triassic rocks of the British Isles. Q. J. Geol. Soc. Lond. 126, $19-47$

Beauchamp, B., Baud, A., 2002. Growth and demise of Permian biogenic chert along northwest Pangea: evidence for end-Permian collapse of thermohaline circulation. Palaeogeogr. Palaeoclimatol. Palaeoecol. 184, 37-63.

Boulouard, Ch., Viallard, P., 1971. Identification duPernien dans la Chaîne Ibérique. C. R. Acad. Sci., Paris 273, 2441- 2444.

Bridge, J.S., 1984. Large scale facies sequences in alluvial overbank environment. J. Sediment. Petrol. 54, 583-588. 
Bridge, J.H., 1985. Paleochannel pattems inferred from alluvial deposits: a critical evaluation. J. Sediment. Petrol. 55, 579-589.

Bridge, J.S., Leeder, M.R., 1979. A simulation model of alluvial stratigraphy. Sedimentology 26, 617-644.

Bryant, M., Falk, P., Paola, C., 1995. Experimental study of avulsion frequency and rate of deposition. Geology 23, 365-368.

Büchl, A., Gier, S., 2003. Petrogenesis and alteration of tuffs associated with continental flood basalts from Putorana, northem Siberia. Geol. Mag. 140, 649-659.

Campbell, C.V., 1976. Reservoir geomery of a fluvial sheet sandstone. Am. Assoc. Pet. Geol. Bull. 60, 1009-1020.

Cant, D.J., Walker, R.G., 1978. Fluvial processes and facies sequences in the sandy braided South Saskatchewan River, Canada. Sedimentology 25, 625-648.

Capote, R., González-Lodeiro, F., 1983. La es uctura herciniana de los afloramientos paleozoicos de la Cordillera Ibérica. In: Comba, J. (Ed.), Libro Jubilar J. M. Ríos 1. , pp. 513-529.

Collinson, J.D., 1970. Bedforms of the Tana River, Nonway. Geogr. Ann. 52 A, 31-55.

Courtillot, V., Renne, P., 2003. On the age of flood basalt events. C. R. Geosci. 335, $113-14$.

Courtillot, V., Jaupart, I., Manighetti, P., Tapponier, J., Besse, J., 1999. On causal links between flood basalts and continental breakup. Earth Planet. Sci. Lett. 166, 177-195.

Crowley, K.D., 1983. Large-scale be configurations (macroforms), Platte River basin, Colorado and Nebraska: primary smuctures and formative processes. Geol. Soc. Amer. Bull. 94, 117-133.

Dickins, J.M., 1993. Climate of Late Devonian to Triassic. Palaeogeogr. Palaeoclimatol. Palaeoecol. 100, 89-94.

Doblas, M., Oyarzun, R., Sopeña, A., Sánchez-Moya, Y., 1993. Variscan-late Variscan-early Alpine progressive extensional collapse of central Spain. Geodyn. Acta 7, 1-14

Doubinger, J., López-Gómez, J., Arche, A., 1990. Pollen and spores from the Permian and Triassic sediments of the Southeastem Iberian Ranges, Cueva de Hierro (Cuenca) to Chelva-Manzanera (Valencia) region, Spain. Rev. Palaeobot. Palynol. 66, 25-45.

Erwin, D.H., 1994. The Permo-Triassic extinction. Nature 367, 231-236

Fielding, C.R., Alexander, J., 2001. Fossils trees in ancient fluvial channels deposits: evidence of seasonal and long-term climatic variability. Palaeogeogr. Palaeoclimatol. Palaeoecol. 170, 59-80.

Fontana, D., Neri, C., Ronchi, A., Stefani, C., 2001. Stratigraphic architecture and composition of the Permian and Triassic siliciclastic succession of Nurra, NW Sardinia. Nat. Brescia. 25, $149-161$.

Gianolla, P., Jacquin, T., 1998. Triassic sequence stratigraphic framework of Westem European basins. In: de Graciansky, P.C., Hardenbol, J., Jacquin, T., Vail, P.R. (Eds.), Mesozoic and Cenozoic Sequence Stratigraphy of European Basins, Spec Publ. S.E.P.M., vol. 60, pp. 643-650.

Gorsky, V.P., Gusseva, E.A., Crasquin-Soleau, S., Broutin, J., 2003. Stratigraphic data of the Middle-Late Permian of the Russian Platform. Geobios 36, 533-556.

Harvey, A.M., 1990. Factors influencing Quatemary alluvial fan development in SE Spain. In: Rachocky, A.H., Church, M (Eds.), Alluvial Fans: A Field Approach. John Wiley, Boston, pp. $247-261$.
Heller, P.L., Paola, C., 1996. Downstream changes in alluvial architecture: an exploration of controls on channel-stacking patterns. J. Sediment. Res. 66, 297-306.

Hemando, S., 1977. El Pérnico y el Triásico de la región de AiyónAtienza (provincias de Segovia, Soria y Guadalajara). Semin. Estratigr. 2, 1-408.

Hotinski, R.M., Bice, K.L., Kup, L.R., Najjar, R.G., Arthur, M.A., 2001. Ocean stagnation and end-Permian anoxia. Geology 29, $7-10$

Hubert, J.F., Hyde, M.G., 1983. Sheet flood deposits of graded beds and mudstones on an alluvial sandflat-playa system, Upper Triassic Blomidon beds, St Mary's Bay, Nova Scotia. Sedimentology 29, 457-474.

Jain, V., Sinha, R., 2003. Hyperavulsive-anabranching Baghmati river system, north Bihar plains, Eastern India. Z. Geomorph. N. F. 47, 101-116

Jin, Y.G., Wang, Y., Wang, W., Shang, Q.H., Cao, C.Q., Enwin, D.H., 2000. Pattern of marine mass extinction near the PermianTriassic boundary in south China. Science 289, 432-436.

Jones, C.M., 1977. Effects of varying discharge regimes on bed-form sedimentary suctures in modem rivers. Geology 5, 567-570.

Kamo, S.L., Czamanske, G.K., Amelin, Y., Fedorenko, V.A., Davis, D.W., Trofimof, V.R., 2003. Rapid eruption of Siberian floodvolcanic rocks and evidence for coincidence with the PermianTriassic boundary and mass extinction at $251 \mathrm{Ma}$. Earth Planet. Sci. Lett. 214, 75-91.

Kelly, S., Olsen, H., 1993. Terminal fans, with reference to Devonian examples. Sediment. Geol. 85, 339-374.

Kidder, D.L., Worsley, T.R., 2004. Causes and consequences of extreme Permo-Triassic warming to globally equable climate and relation to the Permo-Triassic extinction and recoveries. Palaeogeogr. Palaeoclimatol. Palaeoecol. 203, 207-237.

Kraus, M.J., Gwinn, B., 1997. Facies and facies architecture of Paleogene floodplain deposits, Willwood Formation, Bighom Basin, Wyoming, USA. Sediment. Geol. 114, 33-54.

Krull, E.S., Retallack, G.J., 2000. $C^{13}$ organic depth profles from palaeosols across the Permian-Triassic boundary. Evidence for methane release. Geol. Soc. Amer. Bull. 112, 1459-1472.

Lago, M., Arranz, E., Galé, C., 2002. Stephanian-Permian volcanism of the Iberian Ranges and Atienza. In: Gibbons, W., Moreno, T. (Eds.), The Geology of Spain. Geological Society, London, pp. 126-128.

Laming, D.J.C., 1982. The new red sandstone. In: Durrance, E.M., Laming, D.J.C. (Eds.), The Geology of Devon. Exeter U. Press, pp. $148-178$.

Li, S., Finlayson, B., 1993. Flood management of the lower Yellow River: hydrological and geomorphological perspectives. Sediment. Geol. 85, 285-296.

Lo, C., Ching, S., Lee, T., Wu, G., 2002. Age of the Emeishan flood magmatism and relations to Permian-Triassic boundary events. Earth Planet. Sci. Lett. 198, 449-458.

López-blanco, M., Marzo, M., Piña, J., 2000. Transgressive-regressive séquense hierarchy of foreland fan-delta clastic wedges (Monserrat and Sant Llorenc del Munt, Middle Eocene, Ebro Basin NE Spain). Sediment. Geol. 138, 41-69.

López-Gómez, J., 1985. Sedimentología y Estratigrafía de los materiales pérnicos y riásicos del sector SE de la Rama Castellana de 
la Cordillera Ibérica entre Cueva de Hierro y Chelva (Provincia de Cuenca y Guadalajara). Semin. Estratigr. 11, 1-344.

López-Gómez, J., Arche, A., 1992. La unidades litostratigráfrcas del Pérmico y Triásico Inferior y Medio en el Sector SE de la Cordillera Ibérica. Estud. Geol. 48, 123-143.

López-Gómez, J., Arche, A., 1993. Sequence stratigraphy analysis and palaeogeographic interpretion of the Buntsandstein and Muschelkalk facies (Pennian-Triassic) in the SE Ibenan Ranges, E. Spain. Palaeogeogr. Palaeoclimatol. Palaeoecol. 103, 347-361.

López-Gómez, J., Arche, A., 1994. Pérmico y el Triásico del SE de la Cordillera Ibérica. Field Guide: IV. Coloquio Estratigrafia y Sedimentología delPérmico y Triásico de España, Cuenca. 70 pp.

López-Gómez, J., Arche, A., 1997. The Late Permian Boniches Conglomerates Formation: evolution from alluvial fans to fluvial system environments and accompanying tectonic and climatic controls in SE Iberian Ranges, Cen Spain. Sediment. Geol. 114, 267-294.

López-Gómez, J., Arche, A., Calvet, F., Goy, A., 1998. Epicontinental marine carbonate sediments of the Middle and Upper Triassic in the Westemmost part of the Tethys Sea, Iberian Peninsula. Zen albl. Geol. Paläontol. 1 9-10, 1033-1084.

López-Gómez, J., Arche, A., Pérez-López, A., 2002. Permian and Triassic. In: Gibbons, W., Moreno, T. (Eds.), The Geology of Spain. Geological Society, London, pp. 185-212.

Mackey, S.D., Bridge, J.S., 1995. Three-dimensional model of alluvial stratigraphy: theory and applications. J. Sediment. Res., Sect. B Stratigr. Glob. Stud. 65, 7-31.

Marsaglia, K.M., Klein, G.D., 1983. The paleogeography of Paleozoic storm depositional systems. J. Geol. 91, 117-142.

Maslarevic, L., Krstic, B., 2001. Continental Permian and Triassic red beds of the Serbian Karpato-Balcanides. Nat. Brescia. 25, $245-252$.

Menning, M., 1995. A numerical time scale for the Permian and Triassic periods: an integrated time analysis. In: Scholle, P.A., Peryt, T.M., Uhner-Scholle, D.S. (Eds.), The Permian of Northem Pangea. Springer, Berlin, pp. 77-97.

Menning, M., 2001. A Permian time scale 2001 and a correlation of marine and continental sequences using the Illawarra reversal (265 Ma). Nat. Brescia. 25, 355-362.

Menning, M., 2002. A Permian timescale 2000 and correlation of marine and continental sequences using the Illawarra reversal (265 Ma). Nat. Brescia., Monografia 25, 355-362.

Metcalfe, I., Mundil, R., 2001. Age of the Permian-Triassic boundary and mass extinction. Permophile 39, 11-12.

Metcalfe, I., Nicoll, R.S., Mundil, R., Foster, C., Glen, J., Lyons, J., Wany, X., Wang, C., Rome, P.R., Blaek, L., Qu, X., Mao, X., 2001. The Permian-Triassic boundary and mass extinction in China. Episodes 24, 239-244.

Miall, A.D., 1978. Fluvial sedimentology: a historical review. Mem.-Can. Soc. Pet. Geol. 5, 1-47.

Miall, A.D., 1981. Alluvial sedimentary basins: tectonic setting and basin architecture. Spec. Pap.-Geol. Assoc. Can. 23, 1-33.

Miall, A.D., 1992. Alluvial deposits. In: Walker, R.G., James, N.P. (Eds.), Facies Models, Geoscience Canada, pp. 119-142.

Miall, A.D., Jones, B.G., 2003. Fluvial architecture of the Hawkesbury sandstone (Triassic), near Sydney, Australia. J. Sediment. Res. 73, 531-545.
Michaelsen, P., 2002. Mass extinction of peat-forming plants and the affect on fluvial styles across the Permian-Triassic boundary, northern Bowen Basin, Australia. Palaeogeogr. Palaeoclimatol. Palaeoecol. 179, 173-188.

Mohindra, R., Parkash, B., Prasad, J., 1992. Historical geomorphology and pedology of the Gandak megafan, eastem India. Earth Surf. Process. Landf. 7, 643-662.

Mohrig, D., Heller, P.L., Paola, C., Lyons, W.J., 2000. Interpreting avulsion processes from ancient alluvial sequences: GuadalopeMatarraña system (northem Spain) and Wasatch Formation (western Colorado). Geol. Soc. Amer. Bull. 112, 1787-1803.

Morante, R., 1996. Permian and Early Triassic isotopic record of carbon and strontium in Australia and scenario of events about the Permian-Triassic boundary. Hist. Biol. 11, 289-310.

Mundil, R., Metcalfe, I., Ludwig, K.R., Renne, P.R., Oberli, F., Nicoll, R.S., 2001. Timing of the Permian-Triassic biotic crisis: implications from new zircon $\mathrm{U} / \mathrm{Pb}$ data (and their limitations). Earth Planet. Sci. Lett. 187, 131-145.

Mundil, R., Ludwig, K.R., Metcalfe, I., Remne, P.R., 2004. Age and timing of the Permian mass extinctions: $\mathrm{U} / \mathrm{Pb}$ dating of closedsystem zircons. Science 305, 1760-1763.

Nelson, B.W., 1970. Hydrography, sediment dispersal and recent historical development of the Po River delta. In: Morgan, J.P. (Ed.), Deltaic Sedimentation, Modem and Ancient, Spec. Pub. Soc. Econ. Pleont. Min., vol. 15, pp. 152-184.

'Brien, P.E., Wells, A.T., 1986. A small alluvial crevasse splay. J. Sediment. Petrol. 56, 876-879.

Pérez-Arlucea, M., 1985. Estratigrafǐa y Sedimentología del Pérmico y Triásico en el Sector Molina de Aragón-Albarracín (Provincias de Guadalajara y Teruel). Ph thesis, Universidad Complutense, Madrid, 320 pp.

Pérez-Arlucea, M., Sopeña, A., 1985. Estratigrafía del Pérmico y Triásico en el sector central de la Rama Castellana de la Cordillera Ibérica (Provincias de Guadalajara y Teruel). Estud. Geol. 41, 207-222.

Puigdefabregas, C., 1973. Miocene point bar deposits in the Ebro Basin, northem Spain. Sedimentology 20, 133-144.

Ramos, A., 1979. Estratigrafia y Paleogeografia del Pérmico y Triásico al oeste de Molina de Aragón (Provincia de Guadalajara). Semin. Estratigr. 6, 1-313.

Ramos, A., Doubinger, J., 1979. Découverte d'une microflore thuringien dans le Buntsandstein de la Cordillere Iberique (Espagne). C. R. Acad. Sci., Paris 289, 525-528.

Ramos, A., Sopeña, A., 1983. Gravel bars in low sinuosity streams, Permian and Triassic, cen Spain. In: Collinson, J.D., Lewin, J. (Eds.), Modem and Ancient Fluvial Systems, Spec. Publ. Int. Ass. Sedimentol., vol. 6, pp. 31-312.

Ramos, A., Sopeña, A., Pérez-Arlucea, M., 1986. Evolution of Buntsandstein fluvial sedimentation in North-west Iberian Ranges (central Spain). J. Sediment. Petrol. 56, 862-875.

Reichow, M.K., Saunders, A.W., While, R.V., Pringle, M.S., Al'Mukhameder, A.I., Medvedev, A.J., Kidd, N.P., 2002. $\mathrm{Ar}^{40} / \mathrm{Ar}^{39}$ dates from West Siberia Basin: Siberian flood basalt province doubled. Science 296, $1846-1849$.

Renne, P.R., Basu, A.R., 1991. Rapid eruption of the Siberian Trap flood basalts at the Permian-Triassic boundary. Science 253, $176-179$. 
Renne, P.R., Zang, Z., Richards, M.A., Black, M.T., Basu, A.R., 1995. Synchrony and causal relations between Permian-Triassic boundary crisis and Siberian flood volcanism. Science 269 , 1413-1416.

Retallack, G.J., Smith, R.M.H., Ward, P.D., 2003. Vertebrate extinction across Permian-Triassic boundary in Karoo Basin, South Africa. Geol. Soc. Amer. Bull. 115, 1133-1152.

Richards, K., Chandra, S., Friend, P., 1993. Avulsive channel systems: characteristics and examples. Spec. Publ.-Geol. Soc. Lond. 75, 195-203.

Roca, C., Guimerá, J., Salas, R., 1994. Mesozoic extensional tectonics in the SE Iberian Chain. Geol. Mag. 131, 155-168.

Ronchi, A., 2001. Upper Paleozoic and Triassic continental deposits of Sardinia: a stratigraphic synthesis. Nat. Brescia. 25, 139-148.

Rust, B.R., 1981. Sedimentation in an arid zone anastomosing fluvial system, Cooper's Creek, cen Aus alia. J. Sediment Geol. 51, 745-755.

Ryskin, G., 2003. Methane-driven oceanic eruptions and mass extinctions. Geology 31, 741-744.

Salas, R., Casas, A., 1993. Mesozoic extensional tectonics, stratigraphy and crustal evolution during the Alpine cycle of the Eastem Iberian Basin. Tectonophysics 228, 35-55.

Sánchez-Moya, Y., Sopeña, A., Muñoz, A., Ramos, A., 1992. Consideraciones teóricas sobre el análisis de la subsidencia: aplicaciones a un caso real en el borde de la Cuenca riásica Ibérica. Rev. Soc. Geol. Esp. 5, 21-40.

Schumm, S.A., Dumont, J.F., Holbrook, J.M., 2000. Active Tectonics and Alluvial Rivers. Cambridge Univ. Press. 276 pp.

Singh, I.B., Bajpai, N.V., Kumar, A., Singh, M., 1990. Changes in the channel characteristics of Ganga River during the Late Pleistocene-Holocene. J. Geol. Soc. India 36, 67-73.

Sinha, R., Friend, P.F., Switsur, W.R., 1996. Radiocarbon dating and sedimentation rates of Holocene alluvial sediments of N. Bihar plain, India. Geol. Mag. 133, 85-90

Smith, N.D., 1970. The braided river stream depositional environment: comparison of the Platte River with some Silurian clastic rocks, north cen Appalachians. Geol. Soc. Am. Bull. \&1, 2993-3014.

Smith, R.M.H., 1995. Changing fluvial environments across the Permian-Triassic boundary in the Karoo Basin, South Africa and possible causes of terapod extinctions. Palaeogeogr Palaeoclimatol. Palaeoecol. 117, 81-104.

Smith, R.M.H., Ward, P.D., 2001. Pattem of vertebrate extinctions across an event bed at the Permian-Triassic boundary in the Karoo Basin of South Africa. Geology 29, 1147-1150.

Smith, D.B., Brunstrom, R.G.W., Manning, P.I., Simpson, S., Shotton, F.W., 1974. A correlation of Permian rocks in the British Isles. Spec. Rep.-Geol. Soc. Lond. 5, 1-45.

Sopeña, A., 1979. Estratigrafia del Pérmico y Triásico del N de la Provincia de Guadala jara. Semin. Estratigr. 5, 1-329.

Sopeña, A., Virgili, C., Arche, A., Ramos, A., Hemando, S., 1983. El Triásico de la Cordillera Ibérica. In: Comba, G. (Ed.), Geología de España, Inst. Geol. Min. España, vol. 2, pp. 37-61.

Sopeña, A., López-Gómez, J., Arche, A., Pérez-Arlucea, M., Ramos, A., Virgili, C., Hemando, S., 1988. Permian and Triassic rift basins of the Iberian Peninsula. In: Manspeizer, W. (Ed.), Triassic-Jurassic Rifting. Elsevier, Berlin, pp. 757-787
Sopeña, A., Doubinger, J., Ramos, A., Pérez-Arlucea, M., 1995. Palynologie du Permien et du Triassique dans le centre de la Peninsule Iberique. Sci. Geol., Bull. 48, 119-157.

Stampfli, G.M., Borel, G.D., 2002. A plate tectonic model for Paleozoic and Mesozoic constrained by dynamic plate boundaries and restored synthetic oceanic isochrons. Earth Planet. Sci. Lett. 196, 17-33.

Thompson, G.M., Ali, J.R., Sonj, X., Jolley, D.W., 2001. Emeishan Basalts, SW China: reappraisal of the formations type area stratigraphy and a discussion of its significance as a large igneous province. J. Geol. Soc. (Lond.) 158, 593-599.

Tönrqvist, T.E., 1994. Middle and Late Holocene avulsion history of the River Rhine (Rhine-Meuse Delta Netherlands). Geology 22, $711-714$

Twitchett, R.J., Looy, C., Morante, R., Visscher, H., Wignall, P.B., 2001. Rapid and synchronous collapse of marine and terrestrial ecosystems during the end-Permian biotic crisis. Geology 29, $351-354$.

Uttig, J., Piasecki, S., 1995. Palynology of the Permian of the northem continents. In: Scholle, P.A., Peryt, T.M., UlmerScholle, D.S. (Eds.), The Permian of Northem Pangea, vol. 1. Springer-Verlag, Berlin, pp. 236-261.

Van Wees, J.D., Arche, A., Bei jdorff, C., López-Gómez, J., Cloetingh, S., 1998. Temporal and spatial variations in tectonic subsidence in the Iberian Basin (eastem Spain): inference from automated forward modelling of high-resolution stratigraphy. Tectonophysics 300, 285-310.

Virgili, C., Sopeña, A., Ramos, A., Arche, A., Hernando, S., 1983 El relleno post-hercínico y el comienzo de la sedimentación mesozoica. In: Comba, J. (Ed.), Libro Jubilar J. M. Ríos 2. IGME, Madrid, pp. 25-36.

Visscher, H., 1971. The Permian and Triassic of the Kingscourt outlier, Ireland. A palynological investigation related to regional stratigraphic problems in the Permian and Triassic of westem Europe. Spec. Pap.-Geol. Surv. Irel. 1, 1-114.

Walker, R.G., Cant, D.J., 1979. Sandy fluvial systems. In: Walker, R.G. (Ed.), Facies Models, Geoscience Canada. Reprint Ser., vol. l, pp. 23-31

Ward, P.D., Montgomery, D.R., Smith, R., 2000. Altered river morphology in South Africa relate to the Permian-Triassic extinction. Science 289, 174-1743.

Wardlaw, B.R., Schiappa, T..A., 2001. Toward a refined Permian chronostratigraphy. Nat. Brescia. 25, 363-365.

Wignall, P.B., 2001. Large igneous provinces and mass extinctions. Earth-Sci. Rev. 53, 1-33.

Yun, H., Zhang, K., Tong, J., Yang, Z., Wu, S., 2001. The Global Sratotype Section and Point (GSSP) of the Permian-Triassic boundary. Episodes 24, 112-114

Zerfass, H., Lavina, E.L., Schulty, C.L., García, A.J.V., Faccini, V.F., Chemale, F., 2003. Sequence stratigraphy of continental Triassic strata of southemmost Brazil. Sediment. Geol. 161, 85-105.

Zhou, M.F., Malpas, J., Song, X.I., Robinson, P.T., Sun, M., Kennedy, A.K., Lesher, C.M., Keays, R.R., 2002. A temporal link between Emeishan large igneous province (SW China) and the end-Guadalupian mass extinction. Earth Planet. Sci. Lett. 196, $113-122$ 